$$
\text { جامعة المنصـورة }
$$

\section{المنهج المقاصدي لابن القيم في تعليل أحكام الشريعة الإسلامية}

\author{
إعـــداد \\ وفاء عبد الرحمن عبد الوهاب \\ باحثة لارجة الماجستير بقسم الفلسفة \\ كلية الآداب - جامعة المنصورة \\ إشراف - - اف \\ أ.د. السيل محمد عبد الرحمن \\ أستاذ الفلسفة الإسلامية \\ كلية الآداب - جامعة المنصورة
}

مجـلة كلــية الآداب - جامعــة المنصــورة

العلدد الخامس والستون - أغسطس Pالب 


\section{المنـهج المقاصدي لابـز القيم في تعليل أهكام الشريعة الإسلامية}

وفاء عبد الرحمن عبد الوهاب

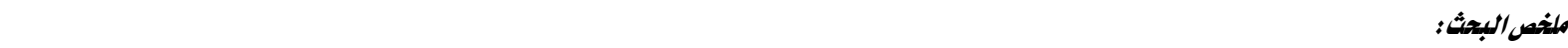

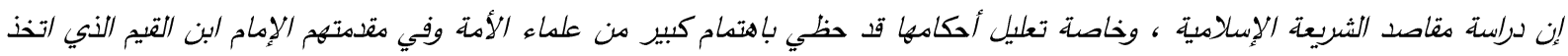

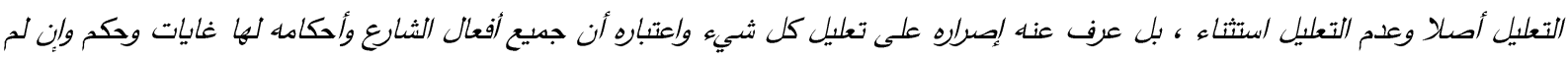

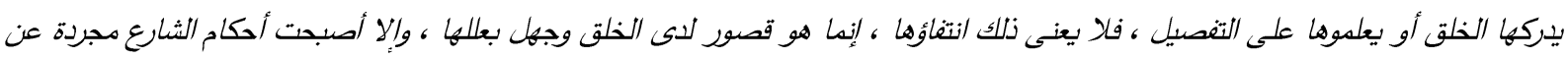

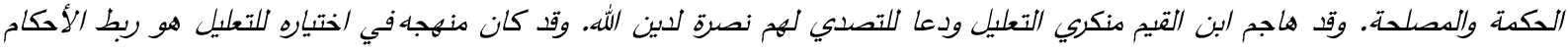

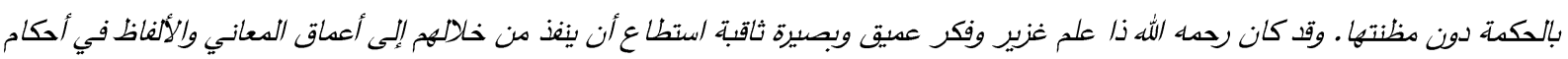

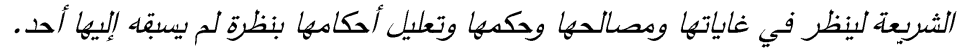
الكلمات الدفتاحية: مقاصد الشريعة ، تعليل الأككام ، ابن القيم.

\section{Abstract :}

The study of the purposes Islamic jurisprudence, especially the explanation of its provisions, has received great attention from the Islamic scholars, especially by Imam Ibn Al-Qayyim, who took the reasoning originally, and nonreasoning exception and he preferred choosing reasoning with wisdom without thinking and insisted on explaining everything and considering that all acts of the Islamic jurisprudence and its provisions have goals and rules for them. He also attacked the deniers of reasoning and called to counter them a victory for the religion of Allah. Using his prolific knowledge and deep thought and insightful insight, he was able to implement to the depths of the meanings and words in the provisions of the Islamic jurisprudence to consider its goals and interests and governance, so Ibn Al-Qayyim could enter into the explanation of the provisions in a manner that was not preceded by one.

ورحمة كلها ، وحكمة كلها ، ومصلحة كلها ، فكل

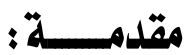

مسألة خرجت عن العدل إلى الجور ، وعن الرحمة إلى ضدها ، وعن المصلحة إلى المفسدة ، وعن الحكمة إلي العبث فليست من الثريعة وإن أدخلت فيها بالتأويل" (†). وقد اهتم ابن القيم بمسألة تعليل الأحكام اهتماما عظيما ، بل وهاجم من رفض التعليل قائلا: "فإثبات الحكمة كمال ونفيه نقص ، والأمة مجمعة على انتفاء النقص على الله، بل العلم انتفاءه (النقص) عن الله تعالى وهو أعلى العلوم الضرورية المستقرة في فطر الخلق ، فلو كانت أفعاله معطلة عن الحكم والغايات المحمودة لتم النقص وهو محال" ("r).

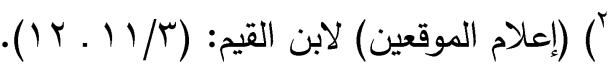

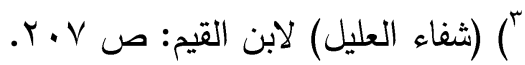

يعتبر الإمام ابن القيم (') من أبرز العلماء الذين اهتموا ببيان مقاصد الثريعة الإسلامية وتوضيح حكمها ومراعاتها لمصالح العباد ، ودعا الناس إلي الاهتمام بالمقاصد وذكر محاسنها قائلا: "الثريعة مبناها وأساسها على الحكم ومصالح العباد في المعاش والمعاد ، وهي عدل كلها ، ') هو الثيخ شمس الدين أبوعبد الله محمد بن أبى بكر بن

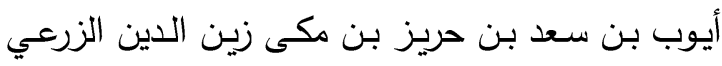

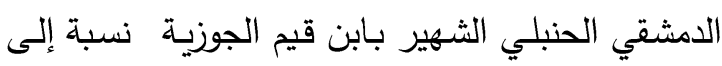
قرية (أزرع) بضم الزاي المشددة ، وهى قرية من حوران

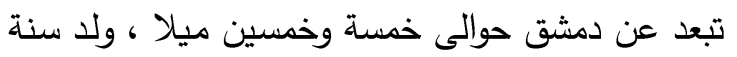

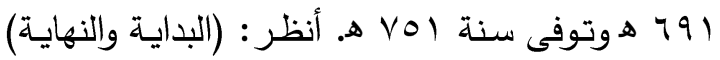
لابـن كثير : (

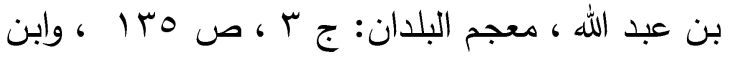

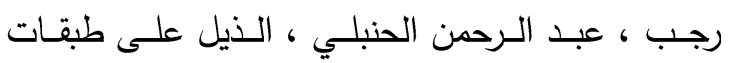

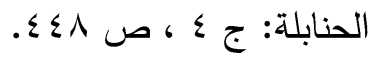




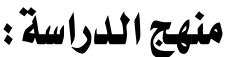

اعتمدت في هذه الدراسة علي المنهج الاستثرائي التحليلي القائم على استخراج آراء الإمام ابن القيم

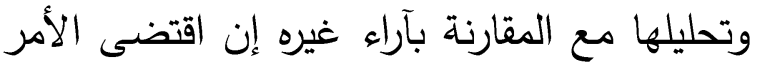
ذلك.

\section{الدراسات السابقة: - الدابة}

على الرغم من كثرة إنتاج ابن القيم العلمي واهتمامه بتوضيح مقاصد الشريعة وتعليل أحكامها والذي يظهر جليا في كتاباته وفقهه ، ندرت الدراسات التي بينت تتاوله لهذا الأمر بالتفصيل وذلك لتفرقها في كتبه ، على الرغم من كثرة

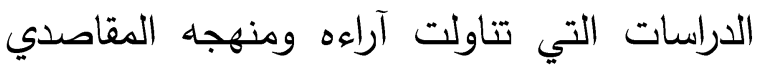

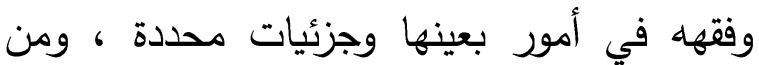
أبرز هذه الدراسات: ا.ابن قيم الجوزية حياته آثاره موارده ، لبكر بن

$$
\text { عبد الله أبو زيد. }
$$

r.ترجيحات ابن قيم الجوزية في كتابه شفاء

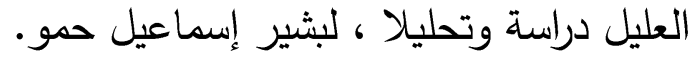
r.أسرار الشريعة من أعلام الموقعين لابن القيم رحمه الله ، لمساعد بن عبد الله السلمان. ـ.سد الذرائع عند الإمام ابن قيم الجوزية وأثره في اختياراته الفقهية ، لسعود بن ملوح سلطان

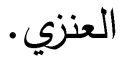

\section{تعريف التعليل:}

التعليل لغة: هو اظهار علية الثيء ، يقال علل الأمر: إذا بين علته وأثبته بالدليل ، فهو تقرير ثبوت المؤثر لإثبات الأثر • ويطلق عليه ما يستدل فيه بالعلة على المعلول ، ويسمى برهانا ، والمراد

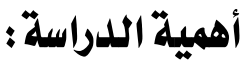

إن البحث في مقاصد الشريعة هو بحث في فلسفة التشريع وأهداف النصوص ، كما أن دراسة هذا باصي الموضوع يدحض المغرضين ويفند آراء المفترين الذين يتهمون الثريعة بالجمود وعدم الوفاء بمنطلبات العصر ، ويبرز مرونتها القابلة للتغيير ويثبت صلاحيتها لكل زمان ومكان. ومن أهمية الموضوع أيضا إبراز دور ابن القيم في مجال المقاصد وجهده في اظهار حكمة التشريع وخاصة اهتمامه بتعليل الأحكام. - الهام

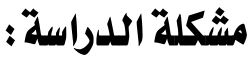

حاولت في هذه الدراسة الإجابة علي عدة نقاط منها: ما هو دور الإمام ابن القيم في تأصيل

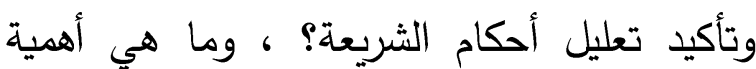
التعليل عند ابن القيم ، وكيف ظهر تأثيره في فقه؟ ، وما مدى جمع شتات ومتثرقات تعليل أحكام الثريعة من بطون كتب الإمام ابن القيم وعرضها في دراسة تيسر الاطلاع عليها؟

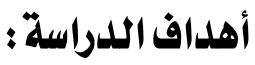

تهدف الدراسة إلى المساهمة في الجهود التي بذلت وستبذل في دراسة مقاصد الثريعة وتعليل أحكامها ، خاصة عند علم من أعلامها مثل ابن القيم ، وتهدف أيضا إلى التعريف بفكر الإمام ابن القيم المقاصدي وبيان منهجه في عرض وشرح وتعليل مقاصد الثريعة وإيراد بعض النماذج التطبيقية لما أصله في هذا الأمر . 
ويعارض الحكمة الإلهية من التشريع في خلود

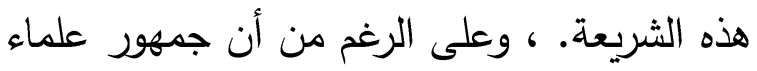

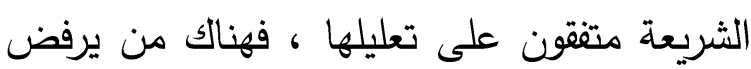

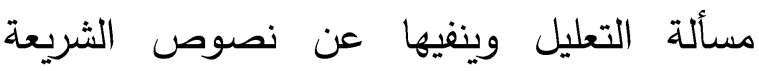

كالظاهرية () (9.

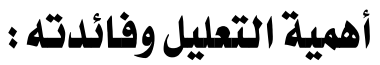

خلافا لكل الثرائع الوضعية على مر العصور

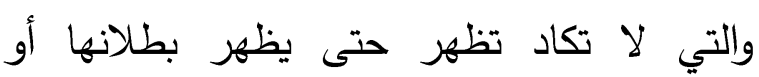
نقصها أو يظهر خلل في أركانها ، لأنها عندما لطانها وضعت لم توضع إلا لتحقق مصالح شخصية

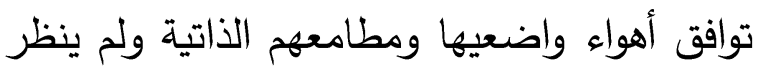

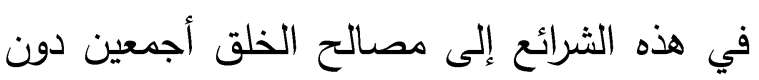

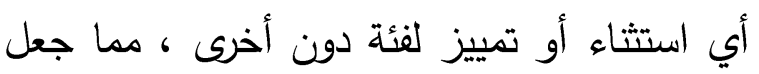

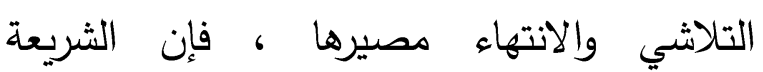
الإسلامية السمحاء التي وضعها خالق الخلق التقاء لتحقق للبشرية جمعاء السعادة والراحة في هذه

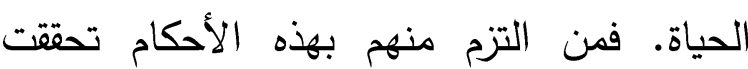
مصالحه ، وكلما ابتعد عنها كلما ضاقت عليه الدنيا ولم يتحقق له الكثير من الخير • قال تعالى:

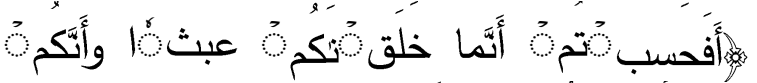

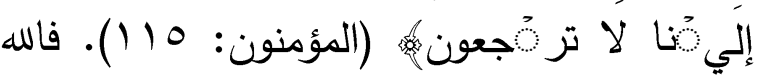

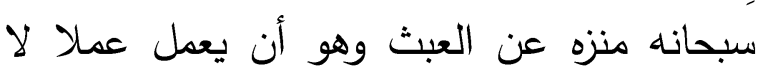
لحكمة ، لأن هذا يعد من اللعب (').'. ولو انو استقرينا الثريعة لوجدناها معللة. فوضع الثريعة إنما هو لمصالح العباد في العاجل والآجل معا. وهذه مسألة قطعية حيث قصد الثارع بتشريعه
هنا بيان العلل (أ). والعلة معنى يحل بالمحل

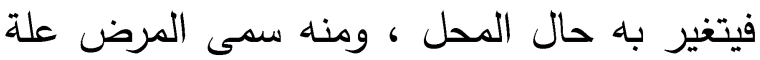

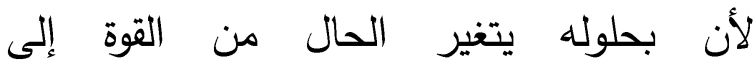
الضعف( (1). التعليل اصطلاحا: يطلق ويراد به أحكام الله عز وجل التي وضعت لهصالح العباد في الآجل والعاجل. وقد يطلق ويراد به بيان علل الأحكام

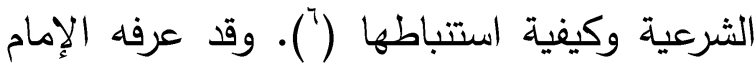

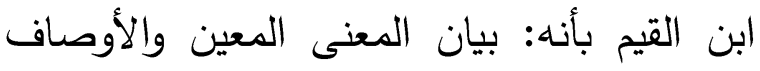
المؤثرة والمعاني المعتبرة والمستفادة من الأحكام

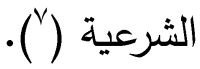
فتعليل الأحكام هو أساس الاجتهاد والاستتباط

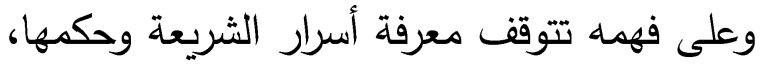

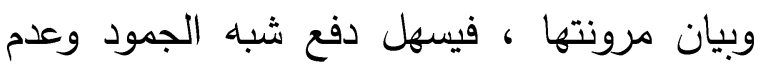

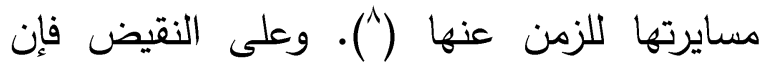

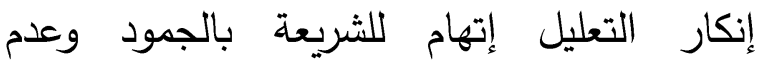
صلاحيتها لكل زمان ومكان. وهو ما ينافي لفالي

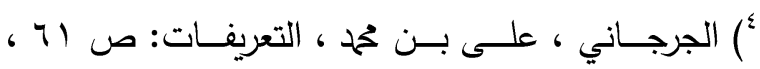

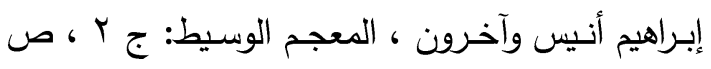
.749

๑) (تاج العروس) للزبيديي ، (لسان العرب) لابن منظور (عل). (ع) (c)

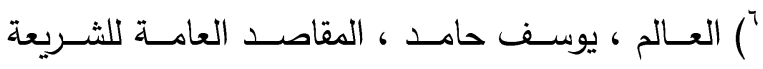
الإسلامية: ص ب آ ، شلبي ، محمد مصطفي ، تعليل

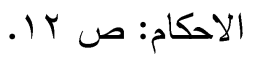

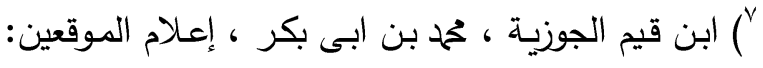

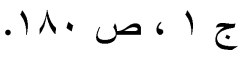

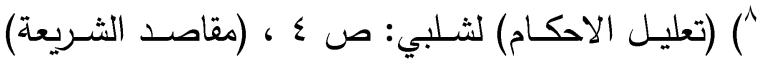

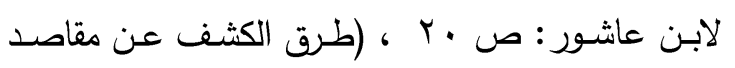

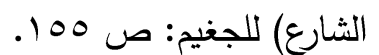


عنهم ("'). بل إن ابن القيم لم يكتف بذلك بل

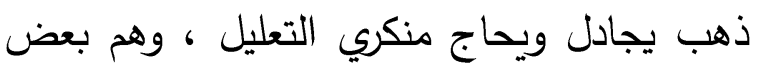

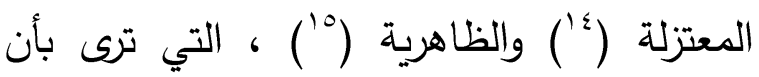
أفعال الله عز وجل وأحكامه غير معللة ، وأن خلقه للمخلوقات وإصداره للأوامر والنواهي إنما هو بمض مشيئته وإرادته. فنجده يقول في دحضه لحجج الرافضين للتعليل: "فالقرآن والسنة مملوءان من تعليل الأحكام بالحكمة والمصالح وتعليل الخلق بها ، والتتبيه على وجوه الحكم التي لأجلها

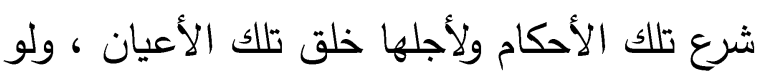
كان في القرآن والسنة نحو مائة موضع أو مائيتين

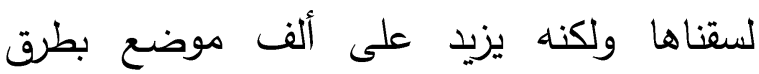

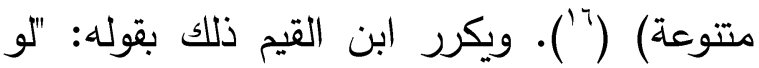
تتبعنا ما يفيد إثبات الأسباب من القرآن والسنة لزاد على عشرة آلاف موضع" ("). فالمتتبع لآيات القرآن الكريم يجد أن الكثير من الن النصوص جاءت تقر وتثبت أن الله عز وجل لم يخلق الخلق عبثا ، بل لغايات ومقصودات وحكم قد تظهر لنا واضحة جلية ، وقد تحتاج إلى بلى بلى استتباط من النصوص الشرعية ، وقد يخفيها الله عز وجل عن خلقه. ومن أمثلة ذلك قوله تعالى:

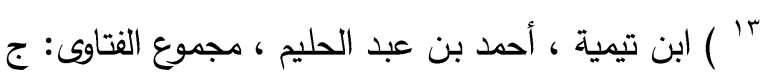

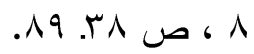

צ' ) أبو الحسن الأشعري ، على ابن إسماعيل ، مقالات

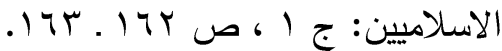

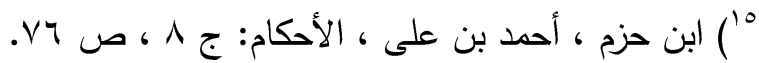

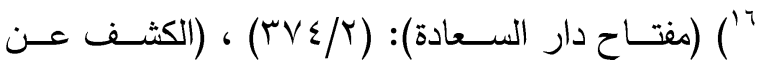

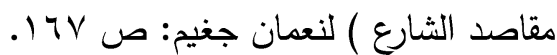

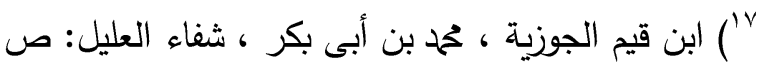

إقامة المصالح سواء كانت ضرورية أو حاجية أو تحسينية. وهذا في جميع أنواع التكليف وفي أحوال

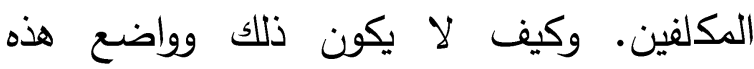
الأحكام هو الله عز وجل. فالله سبحانه وتعالى خالق الخلق وهو أعلم بما يحقق لهم الخير. قال

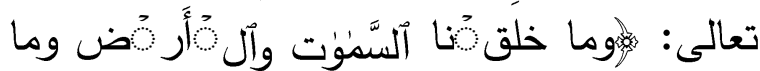

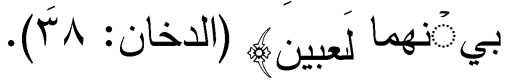

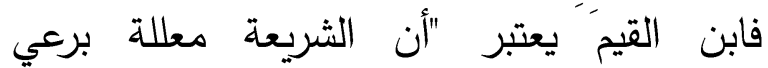
المصالح بغض النظر عن التغريق بين العبادات

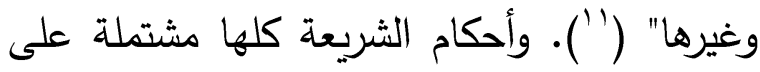
مقاصد الثارع ، وهي حكم كلها ومصالح كلها ولابد للعلماء أن يتعرفوا على التشريع ومقاصده ، وهاه الظاهرة والمستتبطة ، الصريحة بالنص أو الخفية التي تحتاج لاستخلاصها من النصوص "فإثبات

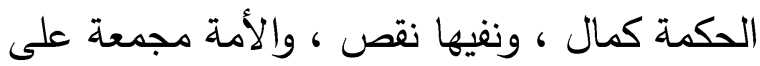
انتفاء النقص عن الله ، بل العلم بانتفائه عن الله

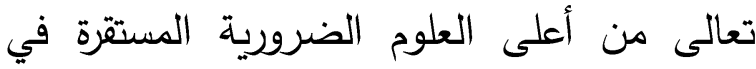
فطر الخلق ، فلو كانت أفعاله معطلة عن الحكم والغايات المحمودة لزم النقص وهو محال" (r').

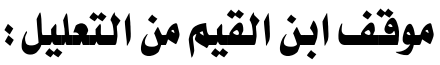
إن الناظر في سيرة ابن القيم وكتبه وفقه يوقن بأنه

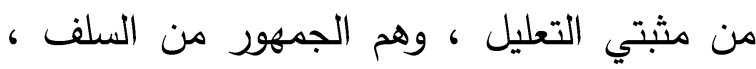
الذين يعتبرون أن أفعال الله عز وجل وكذلك أحكامه معللة ، وأن الله عز وجل إنما خلق الخلق

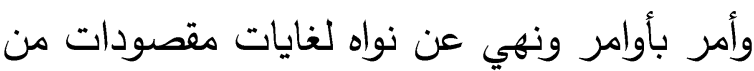
شأنها تحقيق الخير للناس وإبعاد الثقاء والثر نالثرات فئردات ") (نظرية المقاصد عند الثاطبي) للريسوني: ص YM. (Y).

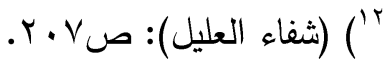


على الشرائع والنبوات والتوحيد إيهام الناس أن التوحيد لا يتم إلا بإنكار الأسباب فإذإ رأي العقلاء أنه لا يمكن إثبات توحيد الرب سبحانه إلا بإبطال

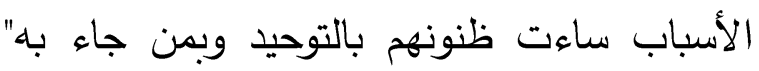

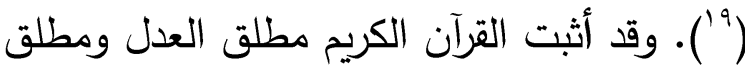
الحكمة لله ، وذلك عن طريق إنكاره التسوية بين

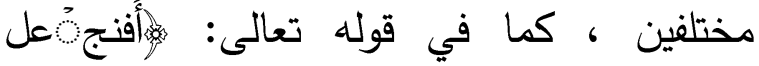

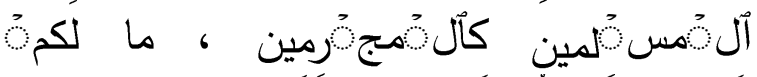

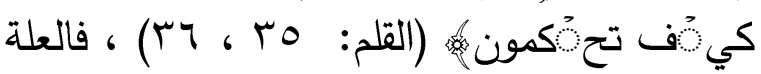
في عدم التسوية بين هذين الصنفين هي التزام طريق الله من جانب المتقين ، وعدم الالتزام من

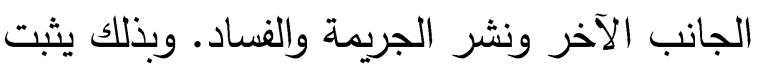

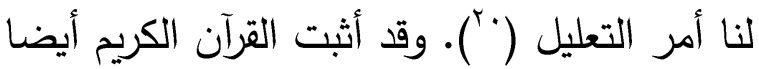

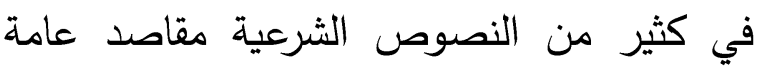
وأخرى خاصه للشريعة الإسلامية فمن المقاصد العامة للشريعة الإسلامية التي أثبتها القرآن الكريم

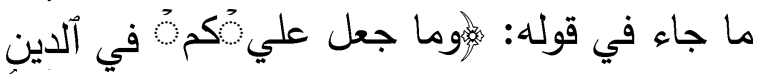

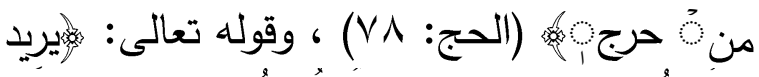

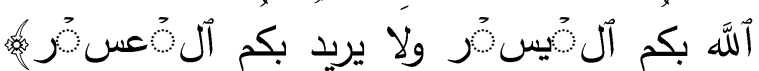
(البقرة: 110). فقد أثثتت هذه النصوص مقد بكد الهد

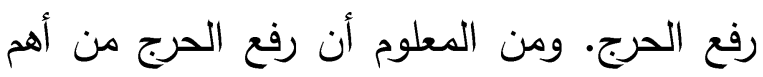
مقاصد الثريعة. ومن المقاصد الخاصة التي

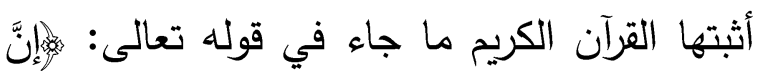

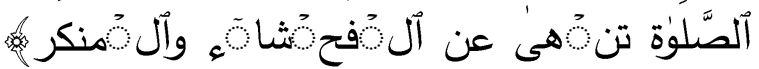

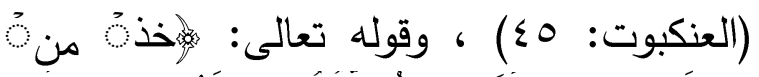

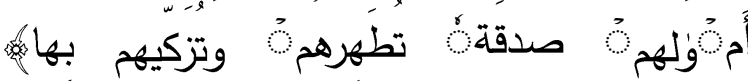

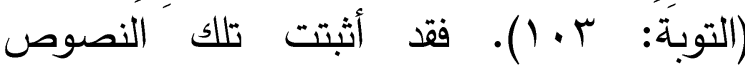

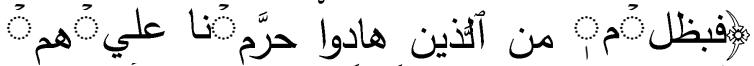

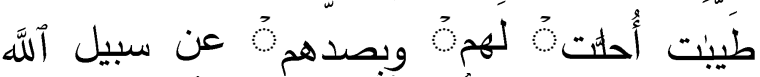

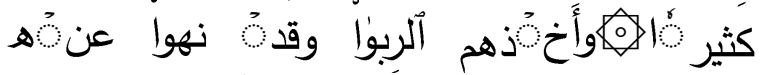

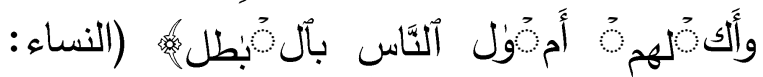

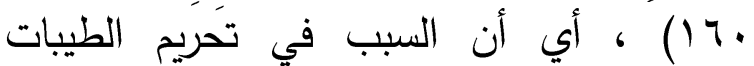
المباحة على اليهود هو ظلمهم وتعديهم على

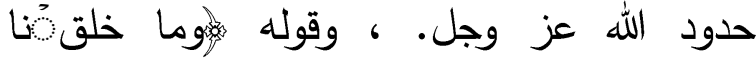

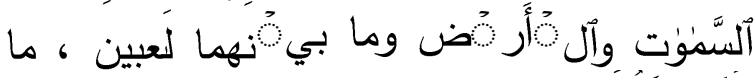

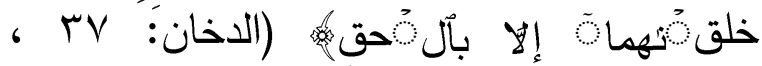
^rr). وأثبت القرآن وعلل أن الدقصود من إرسال الرسل إنما هو الرحمة للعالمين ، فقال تعالى:

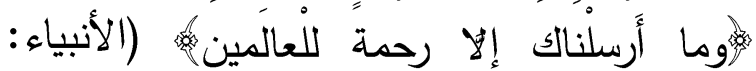

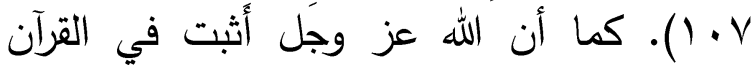
الكريم حقيقة الربط بين الأسباب ومسبباتها فجعل

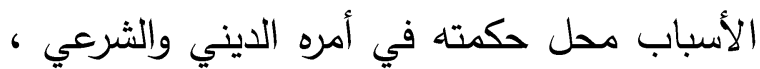
وفي أمره الكوني القدري ومحل ملكه وتصرفه.

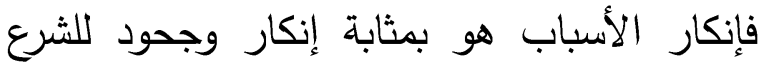
والجزاء ، حيث أن الله عز وجل جعل الجزاء ثوابا كان أم عقابا والأوامر والنواهي والحل لـألأمور والحرمة لها مرتبط جميعها بالأسباب الموجبة لها. وإنكار الأسباب هو بمثابة إنكار للفطرة والعقل والحس. فهذا الكون الفسيح بما فيه من مخلوقات

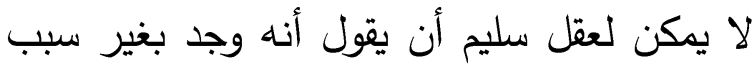
أو أنه خلق عبثا. بل لابد أن تقر جميع العقول أنه إنما خلق لسبب ولعلة ولحكمة (د'). وإنكار الحكم كما قال ابن القيم هو من أعظم الجنايات

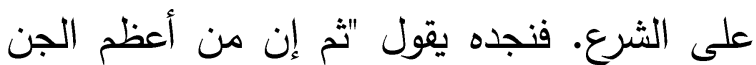




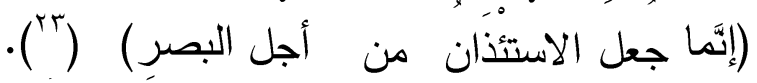

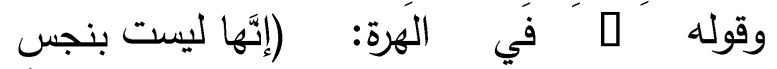

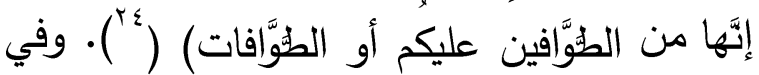

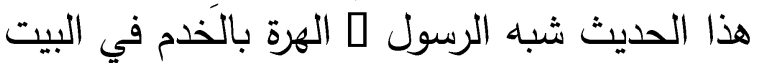
الذين يطوفون بالبيت للخدمة وقيل أن التثبيه هذا بأصحاب الحاجة الذين يطوفون بالبيت طلبا

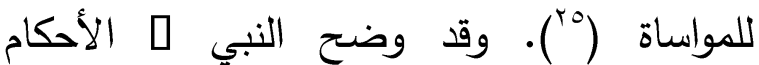
الشرعية لأمته بعدة وسائل من أهمها: أنه استخدم أسلوب ضرب الأمثلة في القضايا التي لها نظائر وأسباب مشابهة لقضايا أخرى. ومن الأمثلة على فلى لإبل

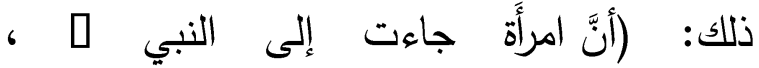

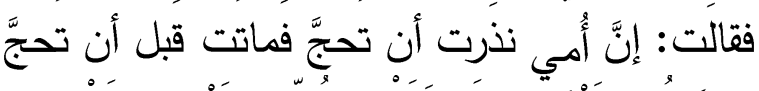

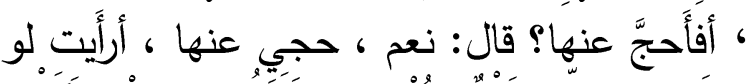

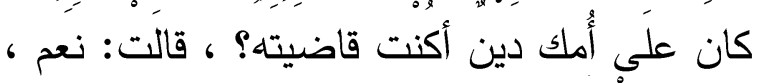

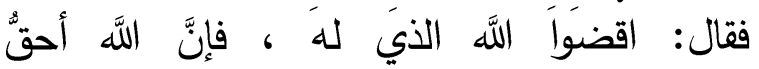

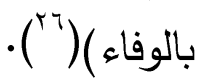

واجتهَ صحابة الرسول ب اجتهادا معلا حيث قاسوا الإمامة الكبرى لأبى بكر الصديق رضى الله

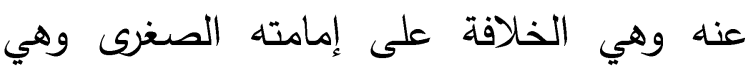
الصلاة بالمسلمين حيث قالوا: رضيه رسول الله إماما لديننا ، أفلا نرضاه لدنيانا؟. والذى عليه التعويل في الجملة والتفصيل أن أصحاب رسول

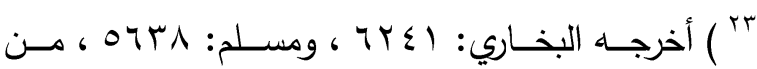
حديث سهل بن سعد الساعدي.

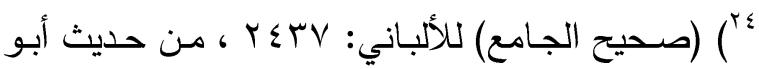

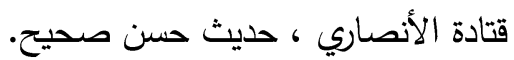

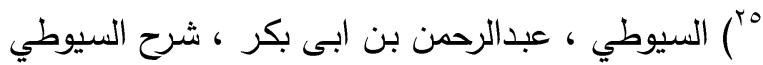

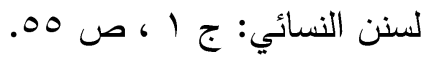
r
المقاصد الخاصة للشريعة كالصلاة في الآية الأولى فهي ناهية عن الفحشاء والمنكر ، والزكاة في الآية الثانية هي سبب لتطهير وتزكية المال (') (باء). وقد جاء التعليل في كتاب الله بصوره المختلفة فتارة تأتى بأسلوب تصرح فيه بالحكمة

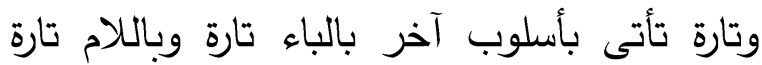

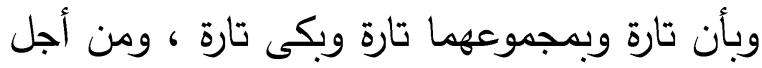
تارة ، وترتيب الجزاء على الثرط تارة وباللفاء السببية تارة ، وترتيب الحكم على الوصف لإنف المقتضى له تارة ، وبلما تارة ، وبأن المشددة تارة

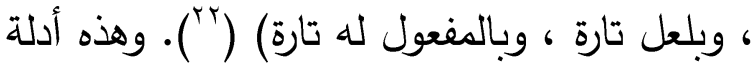

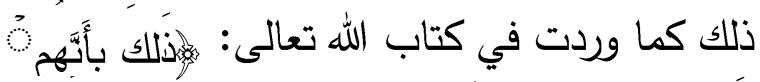

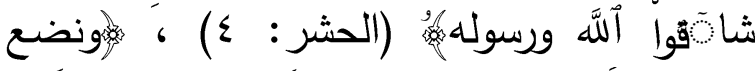

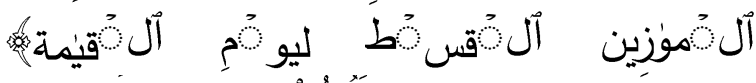

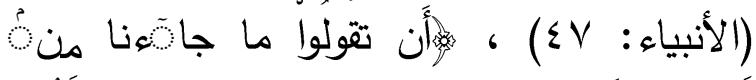

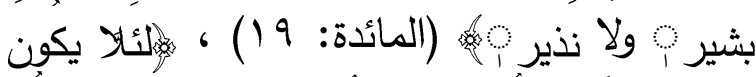

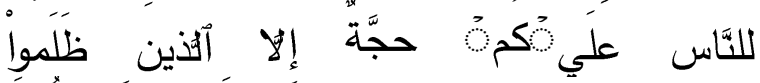

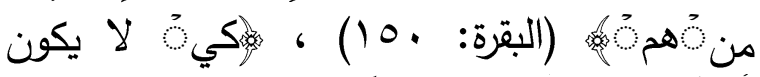

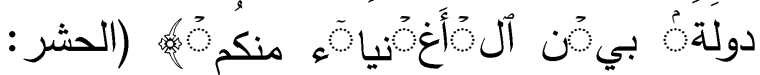

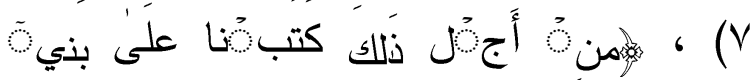

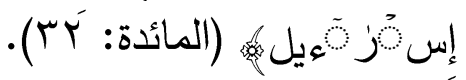
ولو نظرناً إلى سنة رسول الله $[$ لوجدناها مليئة بتعليل الأحكام وقد ذكر النبي 0 علل الأحكام

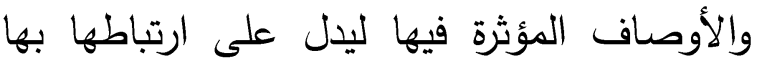
وتعديها بتعدي أوصافها وعللها كقوله: (بآ) اليوبي ، مححد بن سعد ، مقاصد الثريعة الإنـلامية: ص س آن

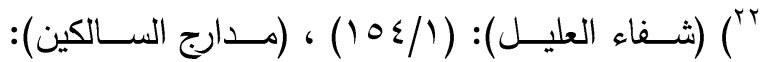

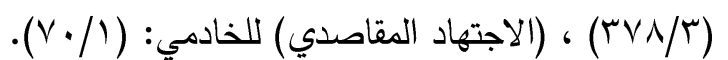


والبحث عن علل الأحكام الثرعية وغاياتها بقوله: "فمن اجتهد في طاعة الله ورسوله فهو دائر بين

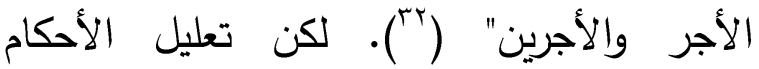

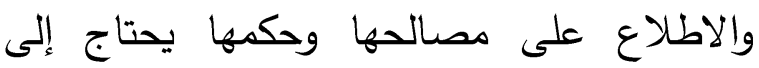
البحث والاستتباط "وحسب العقول الكاملة أن

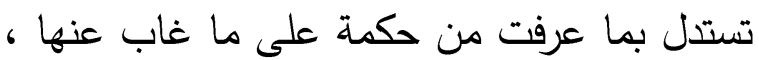
وتعلم أن له حكمة في كل ما خلقه وأمر به وشرعه ، وهل تقتضى الحكمة أن يخبر الله كل

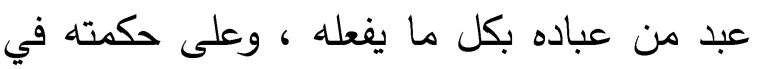

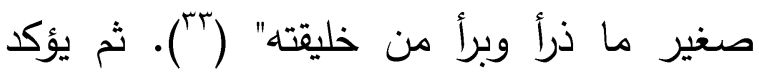
رحمه الله أن الذى يدرك الحكم والغايات هم أهل البصائر النيرة ، والعقول المتفتحة ، فيقول: "فمن

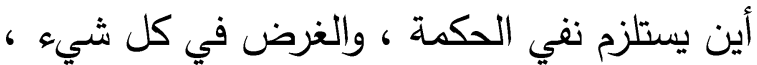
كيف وفيه من الحكم والغايات المحمودة ما هو

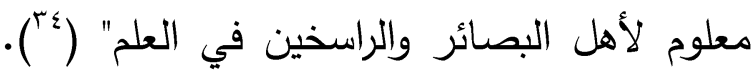
فإن من ينظر إلى هذه الثريعة العظيمة ووسائلها وغاياتها وأغراضها ليجدها مشحونة بالحكم والغايات المقصودة التي فيها سعادة البشرية. "فإن الله سبحانه لم يأمر عباده بما أمرهم به حاجة منها لهادئ إليهم ولا عبثا ، بل رحمة وإحسانا ومصلحة ، ولا بلا بلان نهاهم عنه بخلا منه عليهر ، بل حماية وصيانة عما يؤذيهم ، ويعود عليهم بالضرر إن تتاولوه. فكيف يتوهم من له مسكه من عقل خلوها من الحكم والغايات المحمودة المطلوبة لأجلها. وهل

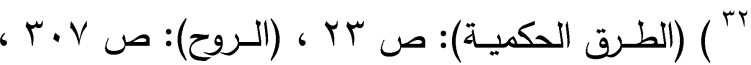

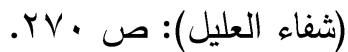

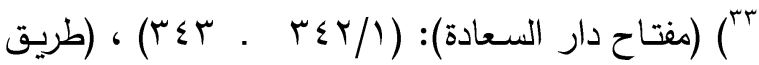

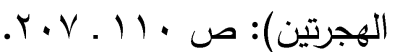

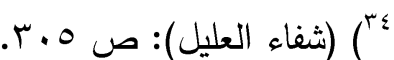

الله [ شهدوا وعللوا ، وكانوا قدوة الأنام وأسوة الإسلام. "فقد كان أصحاب رسول الله [ يجتهدون

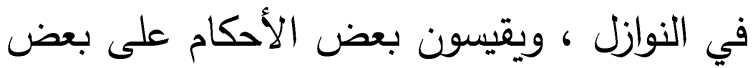

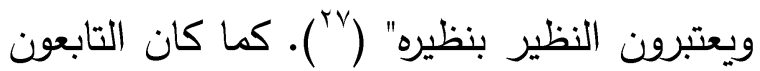

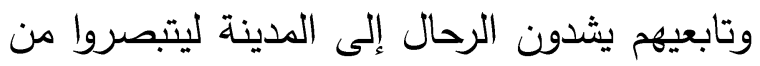

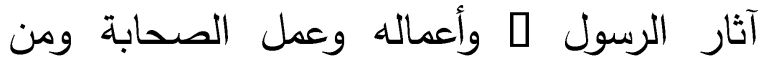

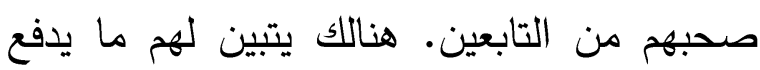
عنهم احتمالات كثيرة في دلالات الألفاظ وليتضح لهم ما يستتبط من العلل تبعا لمعرفة الحكم

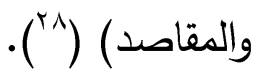

\section{جهود الإمام ابن القيم في اثبات التعليل :}

فاق ابن القيم أستاذه شيخ الإسلام ابن تيمية وكان

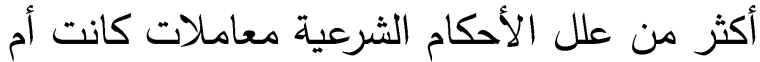
عبادات ، واتخذ التعليل أصلا وعدم التعليل

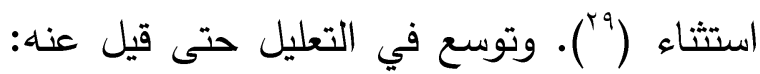

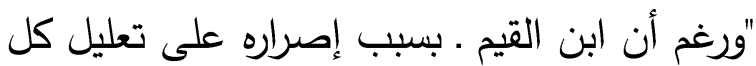
شيء . قد وقع في تعليلات ضعيفة ، كما في

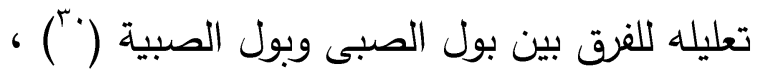
وكما في تعليله لكون صلاة النهار سرية ، وصلاة

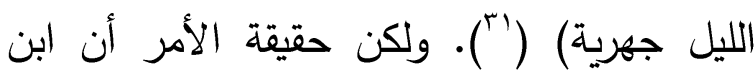
القيم لم تكن تعليلاته ضعيفة ، بل كان ممن شرح الله صدورهم للعلم ، وأضاء قلوبهم بنور الفهم ، وأعطاهم الحكمة. وكان يدعوا إلى الاجتهاد

$$
\begin{aligned}
& \text { "T) (إعلام الموقعين): (101/1). }
\end{aligned}
$$

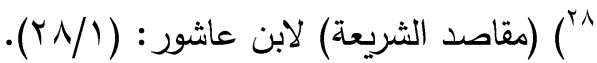

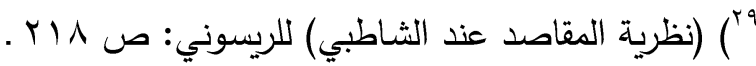

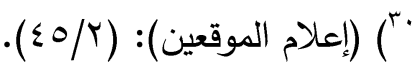

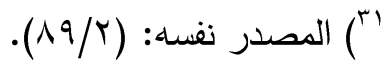


وسعة الرحمة والبر والإحسان ، وأنها من أعظم نعم الله التي أنعم بها على عباده. فلهذا امتن

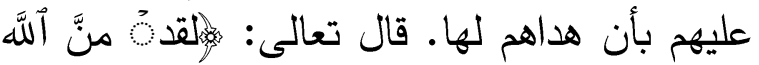

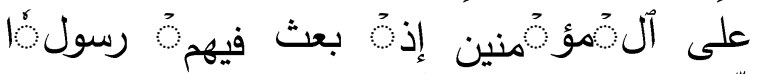

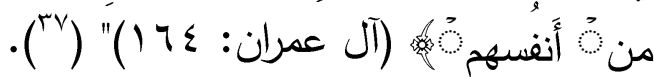
وَّد أكثرَ - رحمده الله - من تعليل الأحكام ، حتى ذكر العلة والحكمة من وجوب الغسل من المني دون البول ، وغسل الثوب من بول الصبية ، ونضحه من بول الصبى. كما ذكر الحكمة من

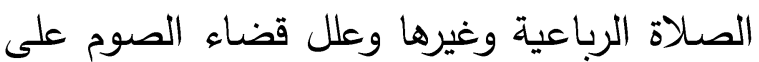
الحائض دون الصلاة. وقد امتلأت كتبه بهذه

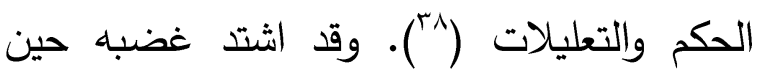
سمع نفاة القياس والتعليل والحكم يدعون أن وفئن الثريعة فرقت بين المتماثلين وجمعت بين المختلفين. حيث فرض الثارع الغسل من المني وأبطل الصوم بإنزاله عمدا وهو طاهر ، دون البول الذى هو نجس. وأوجب غسل غير الموضع الذى خرجت منه الريح ولم يوجب غسله. ونقض الوضوء بمس الذكر دون مس سائر الأعضاء.

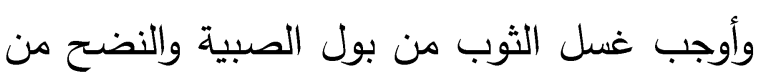
بول الصبى مع تساويهما ، وفرق في العدة بين الموت والطلاق مع استواء حال الرحم فيهما.

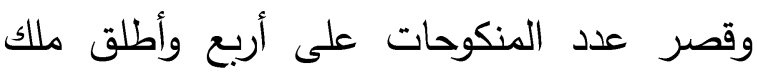
اليمين من غير حصر ، وقطع يد السارق لكونها

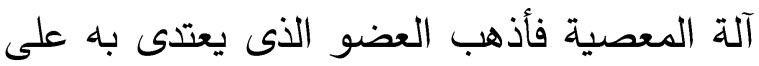

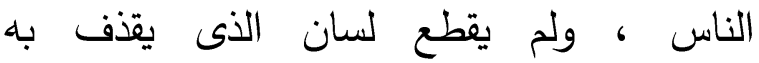

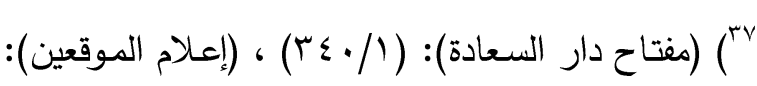
. (07/r)

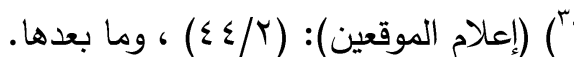

تركت الثريعة خيرا أو مصلحة إلا جاءت به ، وأمرت به وندبت إليه ، وهل تركت شرا ومفسدة

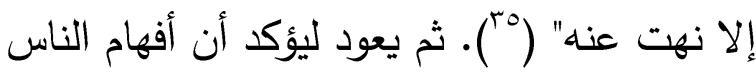
وعقولهم متفاوتة ، وأن عدم معرفتهم وتعليلهح

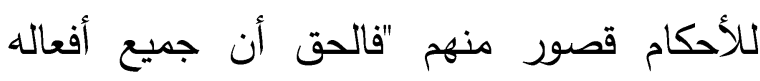

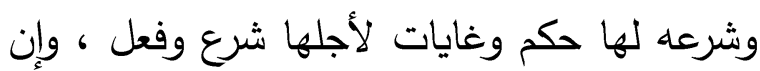
لم يعلمها الخلق على التفصيل ، فلا يلزم من عدم

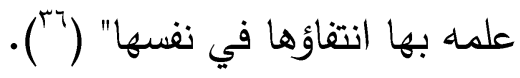
وهذا كله يدل على علم ابن القيم الغزير ، وفكره

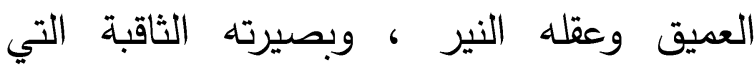
استطاع أن ينفذ من خلالها إلى أعماق المعاني الميله

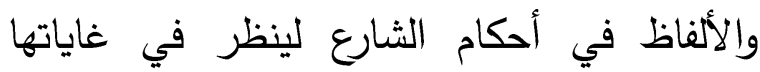
ومصالحها وحكمها ، مما جعله يدخل في التعليل مدخلا متفردا لم يسبقه إليه أحد. فهو يرشد كثيرا إلى التأمل بهذه الثريعة بقوله: "فاذا تأملت الحكمة الباهرة في هذا الدين القويم والملة الحنيفة ، والشريعة المحمدية التي لا تنال العبارة كمالها ولا يدرك الوصف حسنها ، ولا تقترح عقول العقلاء ولو اجتمعت وكانت على أكمل عقل رجل منهم فوقها ، حسب العقول الكاملة الفاضلة إن إن إنال

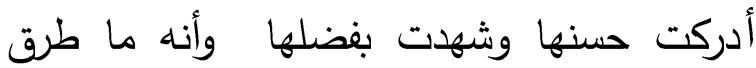
العالم شريعة أكمل ولا أجل ولا أعظم منها. فهي ولفي ولها

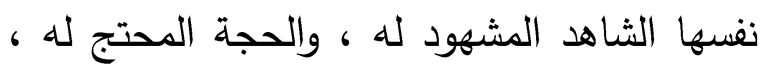
والدعوى والبرهان. ولو لم يأت الرسول ببرهان

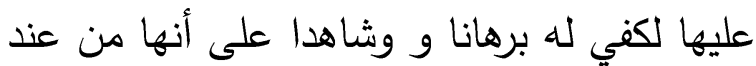

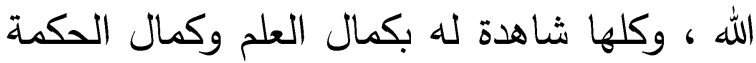

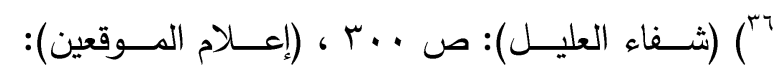
.$(r \leqslant 0 / 1)$ 
الدهر وإماتة الرسل (rr (2). كما ذكر حكمة الصلاة ، بل حكمة كل ركن من أركانها كالسجود والركوع وغيرها ، والزكاة ، والصوم ، والحج ، والجهاد ،

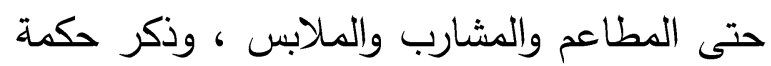

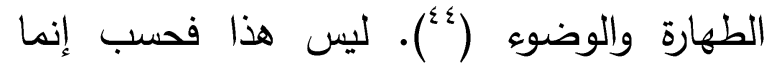
ذهب إلى تعليل ما توقف عن تعليله كبار الأصوليين. حيث ذكر الحكمة في التفريق بين عدة الموت وعدة الطلاق معتبرا أن المقصود

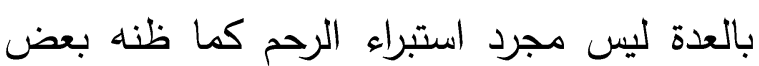
الفقهاء لوجوبها قبل الدخول ، ولحصول الاستبراء بحيضة واحدة ، ولاستواء الصغيرة والآيسة وذوات القروء في مدتها. فلما كان الأمر كذلك قالت طائفة: (هي تعبد محض لا يعقل معناه) ، وهذا باطل لعدة أسباب أولها: أنه ليس في الثريعة حكم واحد إلا وله معنى وحكمة يعقله من عقله ويخفي على من خفي عليه ، ثانيها: أن العدد ليست من باب العبادات المحضة ، فإنها تجب في حق الصغيرة والكبيرة ، والعاقلة والمجنونة ،

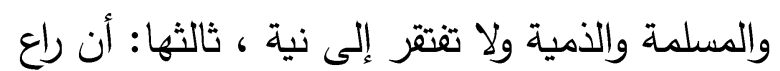
حق الزوجين والولا والزوج الثاني ظاهر فيها. من هنا نجد أنه رحمه الله تعالى علل المعدودات ، وذكر حكمها وغاياتها معتبرا أن هنالك فرق بين الحكمة من عدة الموت ، وعدة الطلاق ، وعدة ، المختلعة ، وميز بين حكمة المطلقة ثلاثا وحكمة عدة الآيسة والصغيرة ، وهكذا (0ء).

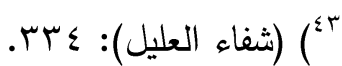

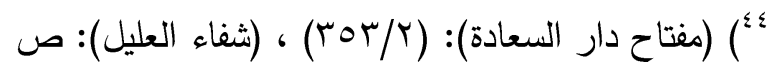

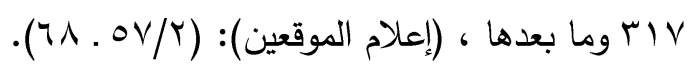
0) (إعلام الموقعين): (T/ / (0) وما بعدها.
المحصنات الغافلات ، ولا الفرج الذى يرتكب به المحرم. وفرق بين صلاة الليل والنهار في السر والجهر • ثم شرع الجهر في بعض صـلاة النهار كالجمعة والعيدين. وسوى بين الرجل والمرأة في العبادات البدنية والمالية كالوضوء والغسل والصلاة والصوم والزكاة والحج، وفي العقوبات كالحدود ، ثم جعلها على النصف من الرجل في الدية والثهادة والميراث والعقيقة ( وراح ابن القيم يعلل كل شيء معتبرا أن ما من حكم أو فعل أو أمر أو خلق دون حكمه ومصلحة فهو عبث وباطل. فعلل كيفية خلق الرأس ، وكثرة ما فيه من العظام ، وكيف جعل الله فيه من الحواس الخمس ، وطبقات العين وقصبة الأنف ، وتعدد الأذنين والعينين ، وأهمية اللسان والقلب

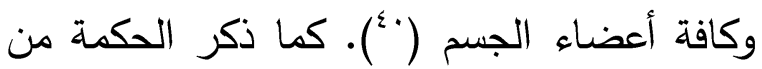
الثمس والقدر ، وطلوع الثمس على العالم ،

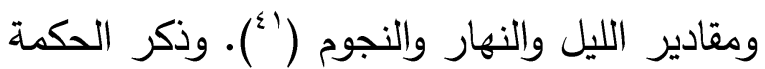
من ابتلاء عباده وحكمة الأمراض والمشاق التي يتعرضون لها ، وأن فوائد الأمراض زادت على ألى مائة فائدة ، وأن هذه الآلام والأمراض والمشاق من أعظم النعم (rr (\&). واستمر - رحمه الله - في تعليله حتى ذكر الحكمة من إبقاء إبليس إلى آخر

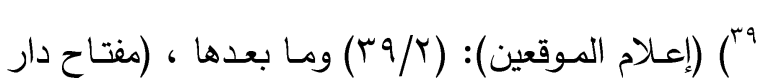

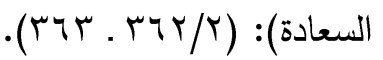

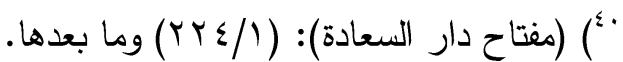

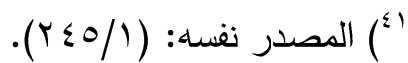

$$
\begin{aligned}
& \text { r }
\end{aligned}
$$

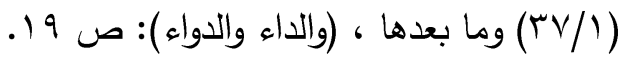


دون الحاجة إلى وسيلة أو وساطة للمساعدة في تحصيل ذلك. فهو الذى أمره بين الكاف والنون ، فلا يحتاج إلى أي وسيلة لتحقيق ما ذكرنا. وبناء على ذلك يكون استخدام الله عز وجل لتحصيل غايات وحكم ومقصودات عبثا ، والعبث في حقه محال (1) (1). ع. استدل أهل الظاهر بنفي التعليل عن أحكام الله عز وجل بأدلة عديدة من أهمها عندهم وأبرزها الاستدلال بقوله : تعالى:

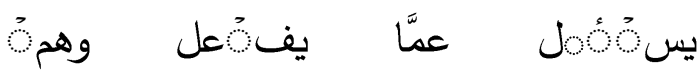

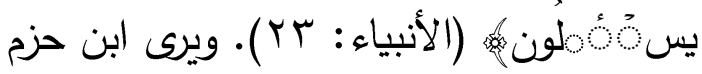
الظاهري أن الله عز وجل قد ميز في هذه الآية بينه وبين البشر فهو الخالق الذى لا يسأل عن أي فعل أو قول صدر عنه ، ولا يحق لأي مخلوق أيا كان سؤال الخالق عز وجل. فالسؤال عما صدر عنه من فعل أو قول في حقه لا يجوز • أما بالنسبة للمخلوق فالسؤال عما صدر عنه من فعل أو قول جائز في حق ذلك المخلوق. فكيف يحق لنا أن نبحث في العلل والمقاصد والغايات التي خلق الله الخلق من أجلها ، أو أصدر الأوامر والنواهي لتحقيقها؟ ألا يعد ذلك من قبيل سؤال الله عز وجل . عن أفعاله وأقواله، وذلك مما نهانا الله عز وجل عنه والذى يتجرأ على الله ويبحث في العلل إنما هو فاسق ، فالعلة كلها

\section{أدلة نفاة التعليل من المعتزلة والظاهرية:} ا. أن القول بأن أفعال الله عز وجل وأقواله جاءت معللة يستلزم أن نصف الله عز وجل بصفة الحاجة إلى الغير وأنه غير كامل بذاته وإنما يحتاج لكماله إلى غيره مما يجعل الله ناقصا ـ والعياذ بالله . ، وبيان نلك أننا إن قلنا: أن تحصيل المصلحة واجب لكل فعل أو قول صادر من الله عز وجل فيكون الفاعل . وهو

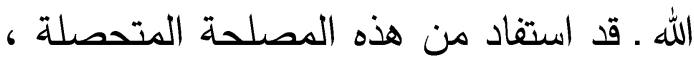
وبذلك يكون مستكملا بحصول هذه المصلحة وناقص بدونها! ، وهذا محال في حق الله عز

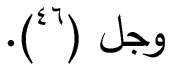

ז. إ ذا سلمنا لكم أن كل فعل أو قول صادر من الله عز وجل لعلة ولحكمة ، فأي حكمة ومصلحة متحققة من خلق الله عز وجل الكفر والفسوق والفساد الواقع من البشر ، وهل لهذه الأمور فائدة ، وهي التي توجب على فاعلها نارا تلظى؟. وإن نظرنا كذلك إلى بعض المخلوقات التي خلقها الله عز وجل وجدنا فيها من المضرة ما الله باه عليم! كالسموم والافتراس التي قد تؤدى إلى هلاك الإنسان

r. أن جميع المصالح والأغراض المتصلة من أفعال وأقوال الله عز وجل إنما يستفاد منها إما بتحقيق السعادة وتحصيل اللذة ، أو يستفاد منها دفع الثقاوة والمضرة. وهذه المصلحة المتحصلة مقدورة إلى الله عز وجل بلا شك 
منفية عن الله عز وجل من باب والتحيز إلى طائفة دون أخرى لينادي بأعلى

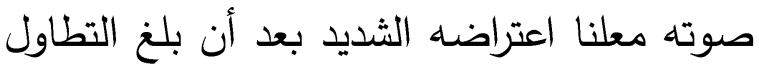
الضرورة( (29). حدا لا يمكن السكوت عنه حين اعتبر أهل موقف ابن القيم من نفاة التعليل ورده على

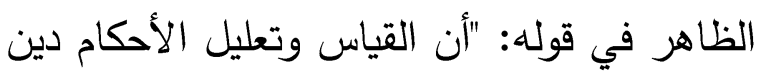

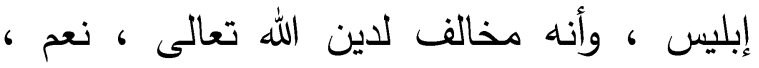

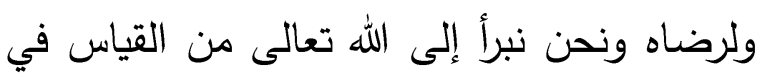
الدين ، ومن إثبات علة الثيء من الثريعة" الثياه

يمكن إجمال ردودابن القيم على جميع شبه نفاة الحكمة وتقنيدها ، وبين فسادها ، على النحو

إذا تتبعنا هذه الفرق وإنكارها التعليل وما استتلت

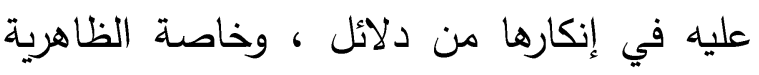

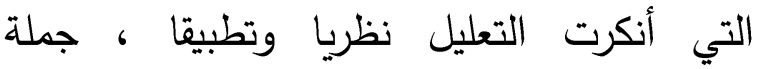
وتفصيلا ، وكانوا أثد من استتكره ، واعتمدوا التعبد المض وعلى رأسهم ابن حزم ، حيث ظهر ذلك جليا في مؤلفاته ، وخاصة كتابه الإحكام في أصول الأحكام ، "كما بالغ في حشر الحجج ضد وخد

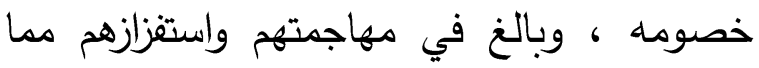
يصعب معه تجاهل موقفه وشبهه ونتائجه ، خاصة وأنه يقدم ذلك كله على أنه اليقين الذى لا لانها

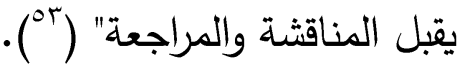
ا ـ الإجابة على الأليل الأول:

أجاب ابن القيم عن هذا الدليل بسؤال وجهه إلى الى لإلى

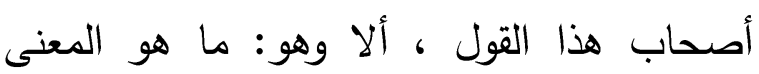

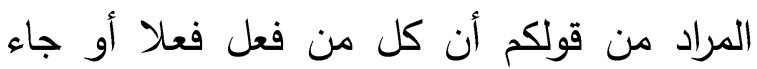
بأمر لتحصيل حكمة وفائدة فإنه يكون ناقصا فرل فعل اء

$$
\text { (الإحكام في قواعد الأحكام): (1) (1) م/ ). }
$$

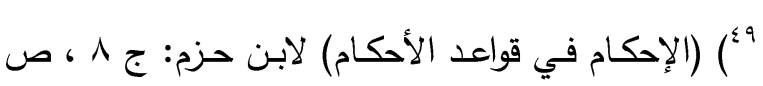
$.07 \mathrm{~V} .070$

خاطب ابن القيم من أنكر التعليل والحكمة والمصلحة التي اعتبرها أساسا في هذا الدين كما في قوله: "الذى هو إثبات الأسباب والوقوف معها

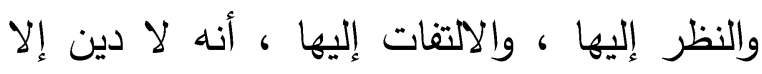
بذلك ، كما لا حقيقة إلا به. فالحقيقة والثريعة مبناها على إثباتها لا على محوها ولا ننكر الا لانه الوقوف معها ، فإن الوقوف معها فرض على كل لإنال

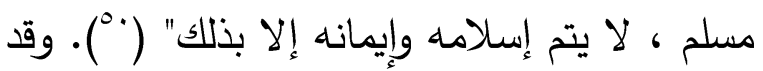

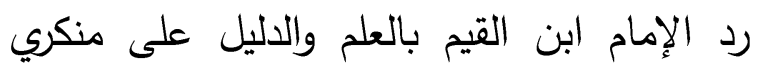

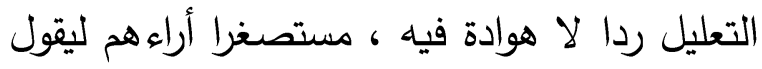
لهم: "الآن حمى الوطيس ، وحميت أنوف أنصار الله ورسوله لنصر دينه ، وما بعث به رسوله ، وأن لحزب الله ألا تأخذهم في الله لومة لائم ، وألا يتحيزوا إلى فئة معينة ، وأن ينصروا الله ورسوله بكل قول حق ، قاله من قاله. ولا يكونوا من الذين

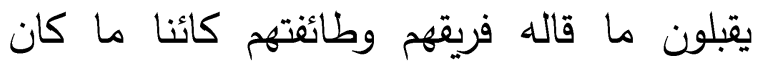
ويردون ما قاله منازعوهم وغير طائنتهم كائنا ما كان ، فهذه طريقة أهل العصبية ، وحمية أهل

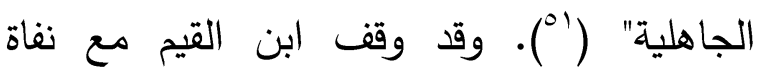
القياس موقفا صلبا بعيدا عن المجاملة والانتصار

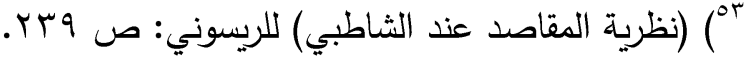

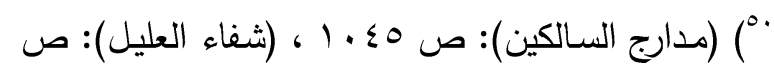
.$r \cdot \mathrm{r}$

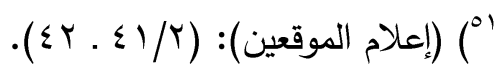


وفي خلقه لهم حكم كثيرة. فالحيوان المفترس الذى تنظر إليه من جانب أنه محقق للضرر لا محالة قد يستفاد منه وتجد له من الفوائد الكثيرة التي تفوق جانب الضرر فيه وهذا الأمر يشبت عند أهل الخبرة في ذلك الأمر ، وبذلك لا يكون وجود ضرر ناتج عن تقصير الإنسان أمام فوائد عديدة سببا للقدح في التعليل وإثباته لأفعال وأقوال الله عز وجل. أما بالنسبة لوجود الأمراض فهذا فيه كل الحكمة ، كيف لا وقد أراد الله عز وجل امتحان خلقه في مدى صبرهم وتحملهم على لهى قدرهم الذى كتبه لهم. فعدم معرفة الناس للحكم واطلاعهم عليها لا يعنى عدم وجودها (10). ب. الإجابة على الاليل الثالث: رد ابن القيم على هذا الدليل القائل بأن الله عز الإله وجل لا يحتاج لوساطة لتحصيل شيء ما ، ونحن

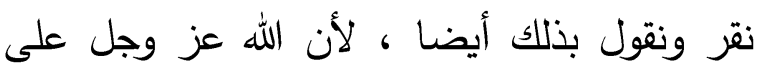
كل شيء قدير، ولكن لا نسلم لكم بأن اختيار المسبب لإيجاد سببه إنما هو من قبيل العبث الذى لا فائدة فيه. إذ لا يمكن أن يوجد الابن إلا لإناليه

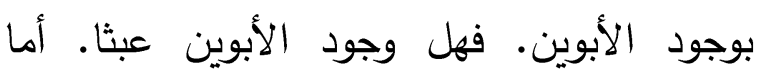
توسط السبب أو الثرط لوجود المسبب أو الو

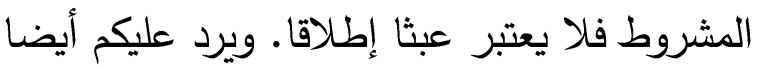
بسؤال تجييون عنه بنفس الإجابة التي نجيب نحن عنكم بها ، ألا وهي: هل يمكن للخالق إيجاد

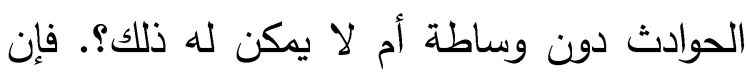
قلتم: نعم ، فنقول لكم إذا وجود هذه الأسباب كما لـا لهان تدعون عبثا وحاشا لله عز وجل أن يخلق شيئا عبثا، وإن قلتم: لا، فبهذه الإجابة تثبتون لله العجز
بذاته مستكملا بغيره؟. فإن كانت إجابتكم عن

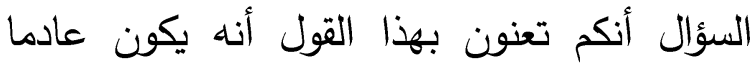

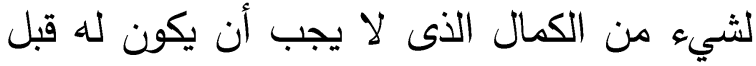
حدوث ذلك المراد. فإن دعواكم هذه تكون باطلة لأنه لا يلزم من فعله لغرض حصوله أولى من

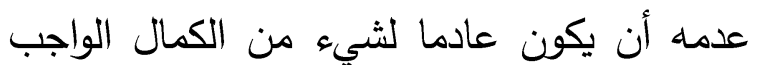

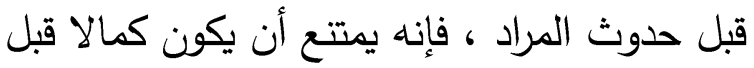
حصوله. وإن كانت إجابتكم عن السؤال أنكم تعنون أنه يكون عادما لما ليس كمالا قبل وجوده.

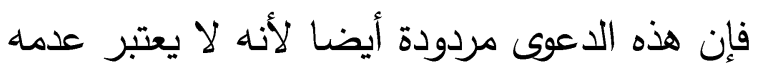

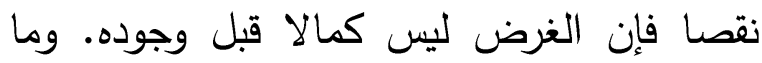
ليس بكمال في وقت لا يكون عدمه نقصا فيه لأن الغرض أو القصد قبل وجوده عدمه أولى. ولا يعتبر نقص وبعد وجوده أولى من عدمه. بل الكمال عدمه قبل وجوده ووجوده بعد وجوده. وإن كانت إجابتكم غير ذلك فلابد من بيانها لإمكانية

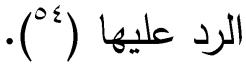

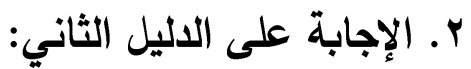
دحض ابن القيم هذه الثبهة برده قائلا: أن الثيء الذى تتحدثن عنه ألا وهو الكفر والعصيان والفساد إنما جاء بسبب مخالفة أمر الله عز وجل الذى فيه الحكمة والمصلحة للبشر. فلما خالف الف الف الفراك هؤلاء الناس أمره وقع فيهم الكفر والفساد. فهذا إذا ليس من أمر الله تعالى وليس من إيجاده ، إنما التزامنا بالحكمة يكون في الأمور التي أوجدها الله عز وجل والتي يكون فيها حكمة وغاية مقصودة. فبالنسبة لوجود الحيوانات المفترسة ، فإن هذا الأمر يرد عليه بأن الله عز وجل أنما خلق الخلق 
معلم البشرية فقد صاروا على النهج القائل بتعليل

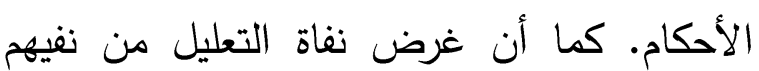

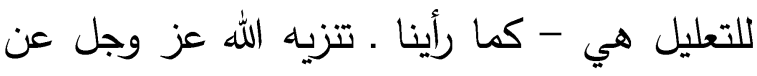
النقائض ، وهذا الأمر استطاع مثبتو التعليل تحقيقه لله عز وجل من خلال إثباتهم أن العقل . وهو سبب التكريم للإنسان وتمييزه عن سائر المخلوقات ـ لا يعارض القول بتعليل الأحكام وهذا

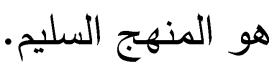
وقد ذكر الإمام ابن القيم أن "إنكار الحكم والتعليل

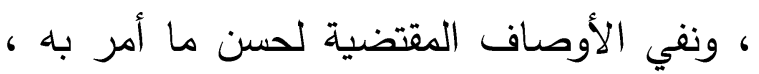

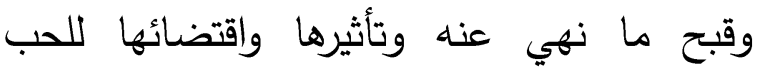
والبغض الذى هو مصدر الأمر والنهي بطريقة

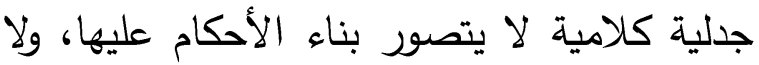

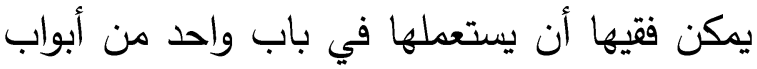
الفقه ، كيف والقرآن وسنة رسول الله 0 مملوءان من تعليل الأحكام بالحكم والمصالح ، ثم ذكر رحمه الله أن للمسألة ثلاثة أصول أساسية هي الأصل الأول: هل أفعال الله سبحانه وتعالى وأوامره معللة بالحكم والغايات؟ وهذه من أجل الجل

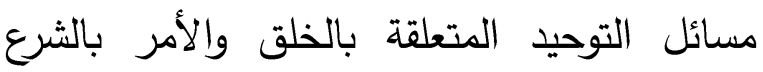
والقدر .

الأصل الثاني: أن تلك الحكم المقصودة فعل يقوم به سبحانه وتعالى قيام الصفة به فيرجع إليه

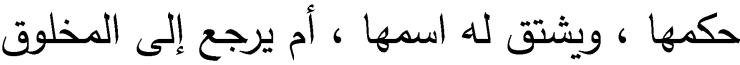

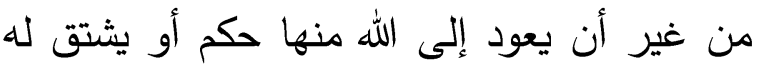

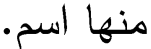

وهذا محال بحقه، وأن قلتم : هذا فرض مستحيل والمحال ليس بشيء نقول لكم وفرضكم محال

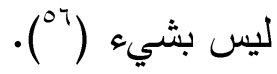
ع. الإجابة على الاليل الزرابع: رد ابن القيم على أهل الظاهرية باستدلالهم بقوله

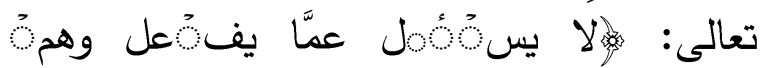

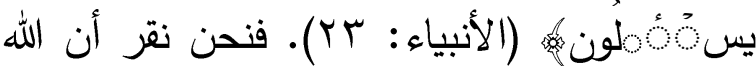
عز وجل لا يسأل عما يفعل ، لكن هذا الأمر ألا

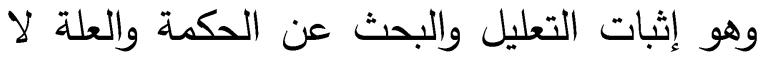
يعنى سؤال الله عز وجل. لذلك نجد أن ابن القيم يقول في توضيح السبب الذى يوجب عدم السؤال كمل علمه وكملت حكمته وليس السبب لعدم حكمته أو لعدم علمه. فهذه الآية جاءت لإثبات العلم الكامل لله عز وجل، وجاءت لإثبات أن شرع

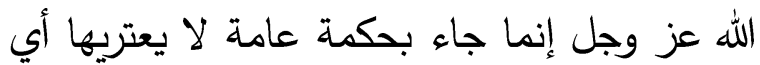
نقص ، فمن قال بعدم الحكمة مستدلا بهذه ال إنما يصف الله عز وجل بعدمها ، وهذا لا يجوز في حق الله عز وجل ، فأين هذا الدليل من إبطال

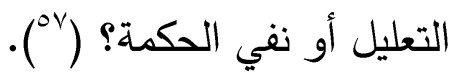
القول الراجح في هذه المسألة ؛ بعد التعرض لأقوال الفقهاء في مسألة التعليل

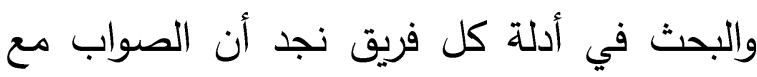
الفريق المثبت للتعليل ، وذلك للأسباب التي ذكرناها سابقا بإثبات القرآن والسنة في أكثر من موضع للتعليل ، كما أن الصحابة رضوان الله عليهح ، وهم الذين فهموا أحكام هذا الدين من لمن الصنان 
الثلاثة. يثبتون الحكمة المقصودة بالفعل في أفعاله تعالى وأوامره. فالمعاصي كلها ممقوتة مكروهة وإن وقعت بمشيئته وخلقه ، والطاعات كلها

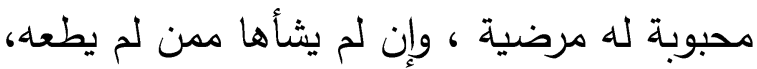
ومن وجدت منه فقد تعلق بها المشيئة والحب. ومن لم يحكم هذه الأصول الثلاثة لم يستقر له في تهلي

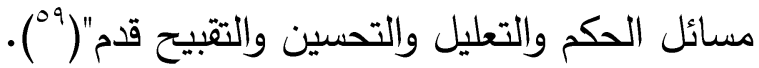
وإن الأشاعرة لما أنكروا وجوب فعل الصلاح والأصلح أورد عليهم المعتزلة ، أو قدروا هم في أنفهه أن يورد عليهح أن الله تعالى لا يفعل شيئا

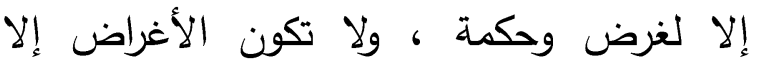
لمصالح. فالتزموا أن أفعال الله تعالى لا تاط الاط الاطراط بالأغراض ، ولا يعبر عنها بالعلل. وهناك سبب آخر لغرض المسألة وهو التنزه عن وصف أفعال الله تعالى بما يوهم المنفعة له أو لغيره ، وكلاهما

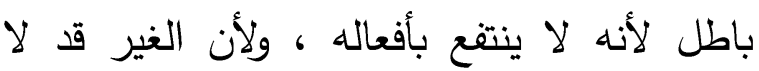

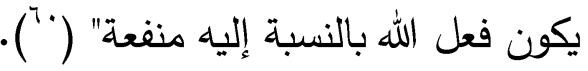
اختيار ابز القيه في منهجه المقاصدي التعليل بـالحكمة لا بـالعلة:

اختلف الفقهاء في ربط الحكم بعلته ، أو بحكته،

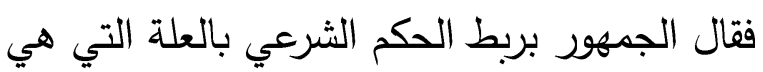
وصف ظاهر منضبط مناسب للحكم. وقال آخرون بربط الحكم الشرعي بالحكمة. ومن منط

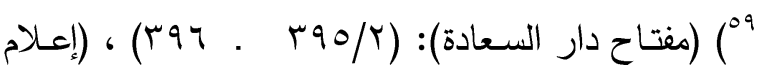

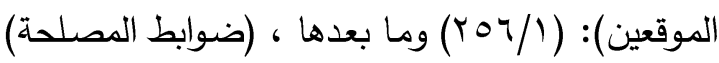

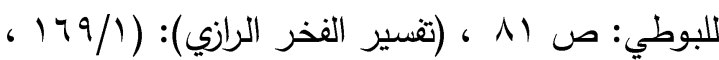

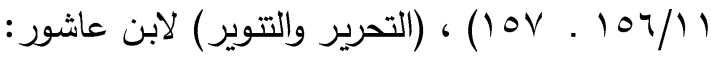
.$(r \Lambda \cdot / 1)$

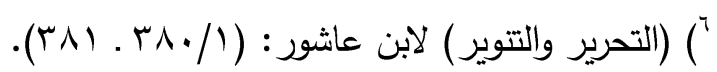

الأصل الثالث: هو تعلق إرادة الله سبحانه بجميع

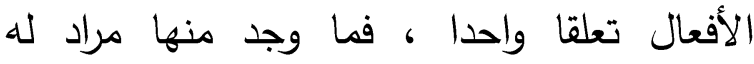
محبوب مرضى طاعة كان أو معصية ، وما لم يوجد منها فهو مكروه له ، مبغوض غير مراد ، طاعة كان أو معصية. فهو يحب الأفعال الحسنة التي هي منشأ الدصالح. وإن لم يثأ تكوينها

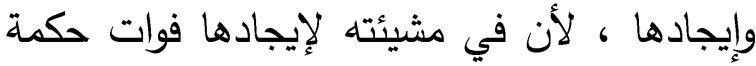

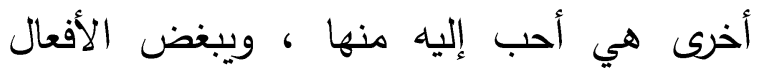

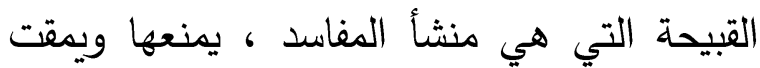

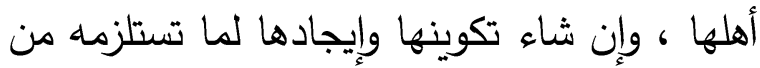
حكمة ومصلحة هي أحب إليه منها. وقد اختلف الناس فيها قديما وحديثا إلى اليوم. وإذا نظرنا إلى الى

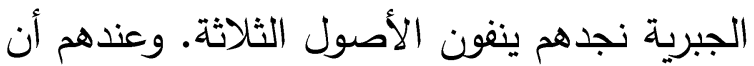
الله لا يفعل لحكمة ، ولا يأمر لحكمة ، ولا يدخل

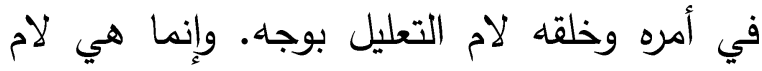
العاقبة. كما لا يدخل في أفعاله باء السببية وإنما لإنا

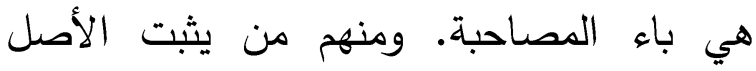

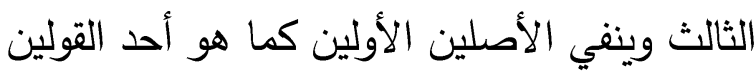
للأشعري ، وقول كثير من أئمة أصحابه وأحد الأدين

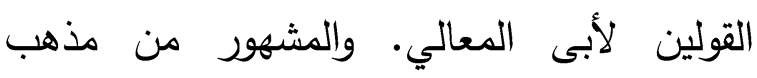
المعتزلة إثبات الأصل الأول وهو التعليل بالحكم والمصالح ، ونفي الثاني بناء على قواعدهم الفاسدة في نفي الصفات. فأما الأصل الثالث فهر فيه ضد الجبرية من كل وجه. فإنهم لا يثتبن لأفعال العباد سوى المحبة لحسنها ، والبغض لهض لهن لقبحها ، وأما المشيئة لها فعندهم أن مشيئة الله لا لالئل

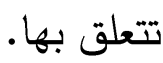
أما أصحاب القول الوسط ، وهم أهل التحقيق من

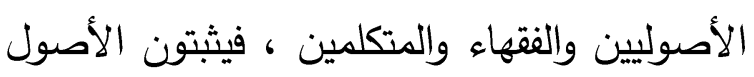


وقد سار ابن القيم علي نفس المنهج الذي اختاره

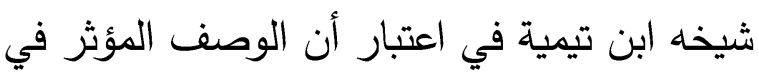

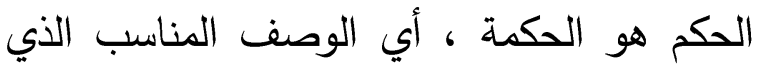

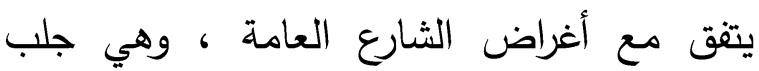

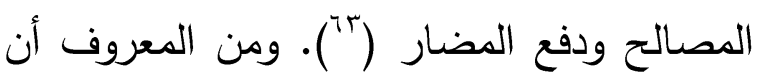
الحنفية يقرون بأن القياس أساسه العلة المشتركة بين الأصل والفرع ، وهي التي تؤثر في ثبوت لئن الحكم في الأصل ، فيثبت بمقتضاها الحكم في

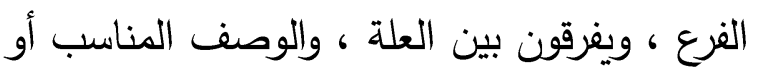

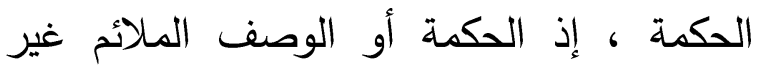

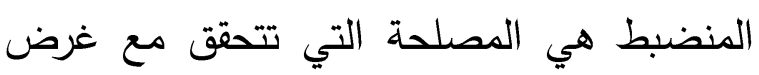

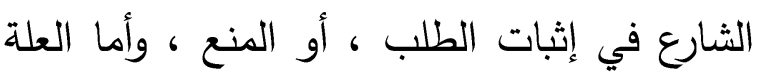
فهي الوصف الملائم المنضبط الذي من شأنه أن الن الن النيا يكون الحكم أثر الارتباط بينهما. والعلة في أكثر لترن

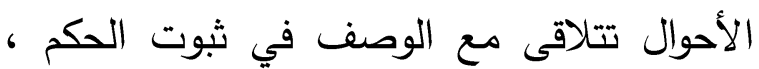

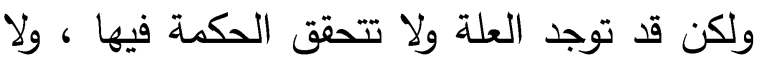

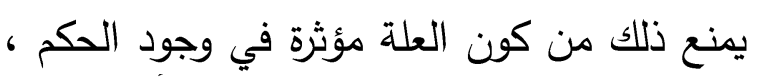
ولذلك قالوا: إن العلة مناط الحكم وجودا وعدما ،

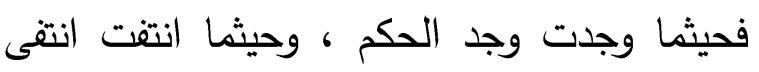
الحكم. أما الحكمة فليس لها هذه القوة (ئج). وفي بيان ابن القيم لمنهجه في ربط الأحكام بالحكمة ، لا بالعلة يقول وهو يناقش مسألة

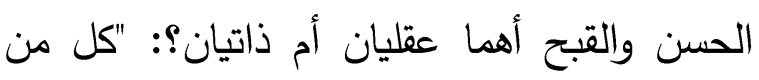

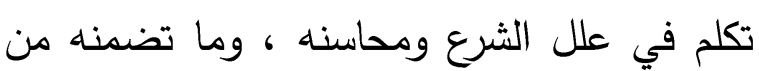
المصالح ودرو المفاسد ، فلا يمكنه ذلك إلا بتقرير

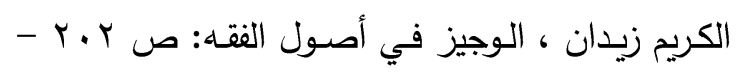

r.r

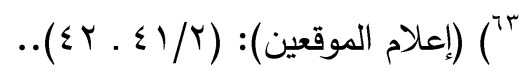
צ'
المتقرر أن ما شرعه الله من أحكام لم يشرعه إلا

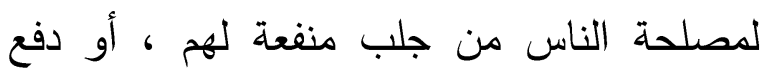
مضرة عنهم ، ولذا كانت تلك المصلحة هي الغاية المقصودة من التشريع ، وسميت لذلك بحكمته.

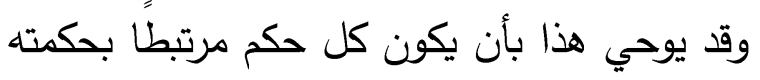
، ومبنيا عليها ، بحيث يرتبط وجوده بوجودها ليكان

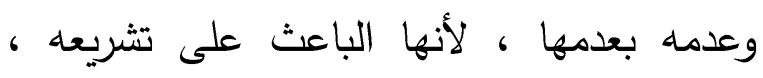
والغاية المقصودة منه. ولكن من استقراء الأحكام

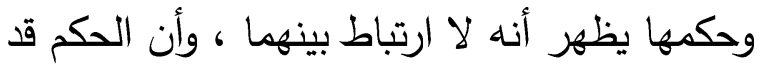
يوجد بدون حكمته في بعض الجزئيات حيث تكون الحكمة غير ظاهرة ولا تدرك ، وليس من اليسير

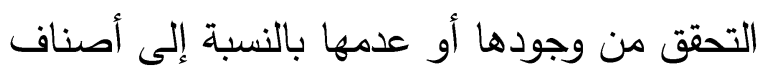

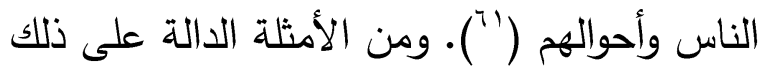
إباحة الفطر في رمضان للمسافر دفعا لما يلحقه في سفره من مشقة بسبب الصيام ، فالمشقة تختلف تبعا لاختلاف حال السفر وحال ولا يجوز أن يرتبط حكم بحكمته لما في ذلك من الحرج

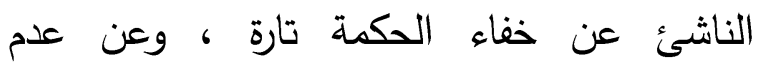
انضباطها تارة أخرى ، لهذا لم يربط الثارع

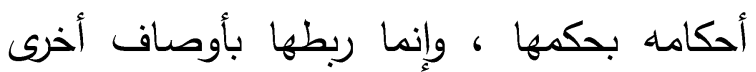
ظاهرة منضبطة مناسبة للحكم. ومعنى مناسبتها له: أن يكون ارتباط الحكم بها وبناؤه عليها من شأنه أن يحقق الحكمة التي من أجلها شرع وهو الهو

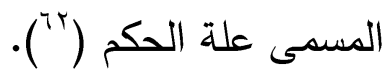

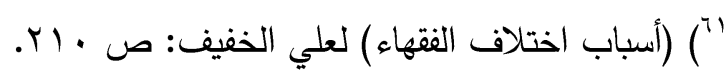

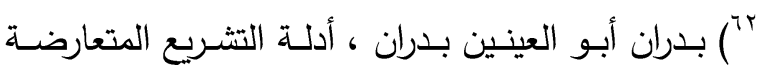

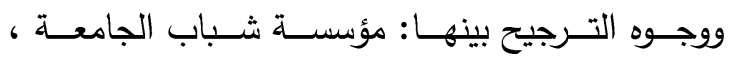

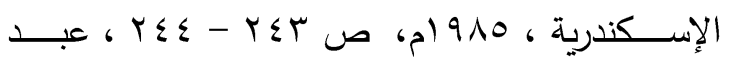


بأجنبية ولا قرابة" ("T). وهذا يعني أن التعليل بالعلة ليس على إطلاقه. فالعلة ليست منضبطة في تقصيلاتها حين لا يكون منصوصا عليها. وإنما فيها خلاف أيضا ، وذلك لسببين هما: أولهما: أن مسالك العلة ليست طريقا واحدا ثابتا لإدرالك العلة ، بل هنالك مسالك عدة. وهذه المسالك المختلفة تؤدي إلى الاختلاف في تقدير العلة ، ومنها: - العال 1. قد يكون النص مسلكا للعلة ، ولكنه ظني ومان الدلالة عليها ، أو يومئ إليها. r. من مسالك العلة: السبر والتقسيم. وهو مسلك الك التهال يختلف المجتهدون فيه في العلة.

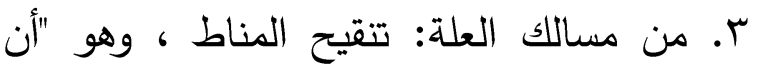

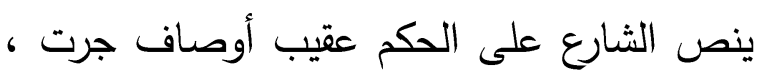

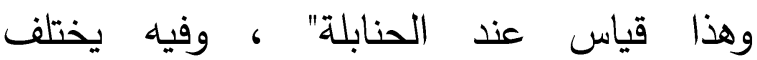
الأصوليون والمجتهدون فيما يصلح للتعليل وما لا

نصلح ("iv)

ثانيهما: حين لا تكون العلة منصوصة فإن الفقهاء يختلفن في إدراكها ، فإدراك الصفات المؤثرة في

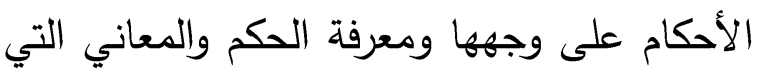
تضمنتها الشريعة من أشرف العلوم ، فمنه الجلي الذي يعرفه كثير من الناس ، ومنه الخفي الذي لا يعرفه إلا خواصهم. ولهذا صار قياس كثير من لن

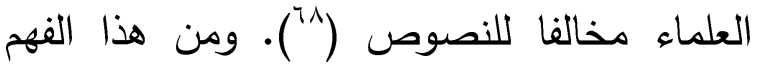
جعل الحنفية العلة الصغر في منع زواج البكر

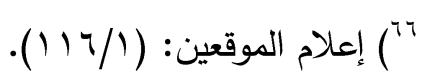

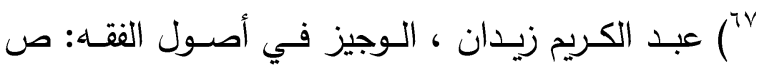

$$
. V T V
$$

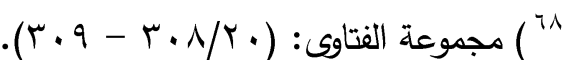

الحسن والقبح العقليين ، إذ لو كان حسنه وقبحه بمجرد الأمر والنهي ، لم يتعرض في إثبات ذلك الك الثين

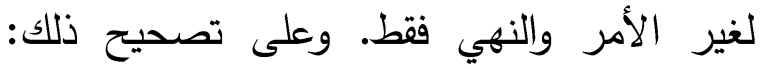
فالكلام في القياس ، وتعليق الأحكام بالأوصاف تصني المناسبة المقتضية لها ، دون الأوصاف الطردية

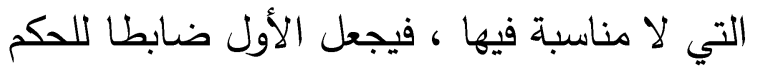
دون الثاني ، لا يمكن إلا على إثبات هذا الأصل لأل الأل ، فلو تساوت الأوصاف في أنفسها لانسد باب التاب الآل القياس والمناسبات والتعليل والدصالح ومراعاة الأوصاف المؤثرة دون الأوصاف التي لا تأثير لها" ( الأن) ونستطيع توضيح منهج ابن القيم في ربط الأحكام بالحكمة دون مظنتها بما يلي: أولا: يعلق ابن القيم على القول بأن التعليل يكون باني

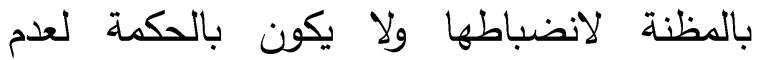

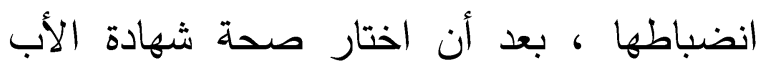

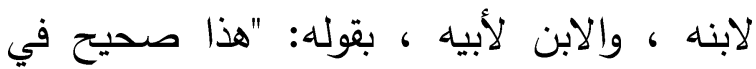

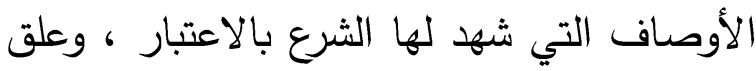

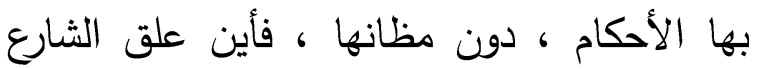

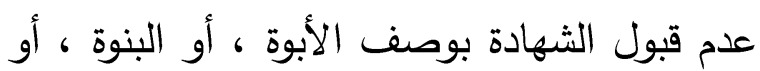

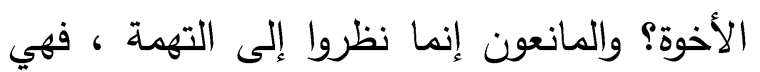
الوصف المؤثر في الحكم ، فوجب تعليق الحكم به وجودا وعدما ، ولا تأثير لخصوص القرابة ولا

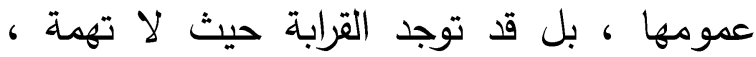
وتوجد التهمة حيث لا قرابة. والثارع إنما علق قبول الشهادة بالعدالة وكون الشاهد مرضيا ، والهال وعلق عدم قبولها بالفسق. ولم يعلق القبول والرد 
العامة للشريعة في كل حكم من الأحكام ، وتعين المقاصد الثرعية في الجزئيات والكليات معا. وبذلك يكون الفقه قريب من متعارف الناس ومصالحهم ، ويمكن وصفه بأنه فقه سلفي نصي منعارفي

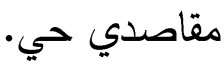
ثانيهما: من الثابت أن علل الأقيسة لا تكون عامة

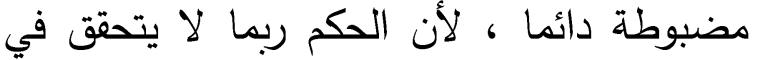
بعض الجزئيات. فكان الحنفية يعالجون ذلك لك بالاستحسان ، وذلك بقياس آخر فيه وصف ملائم أو حكمة أخرى تتحقق فيها المصلحة. أما ابن ولن فئل تيمية وتلميذه ابن القيم فكلاهما جعل القاعدة غير شاملة إذا لم تتحقق الحكمة في موضع ، وأدخلها في عموم حكمة أخرى غير الأولى. وبهذا نجد النظرين متقاربين غير متباعدين في هذا الموضع، الهن بيد أن ابن تيمية وابن القيم يقربان الفقه من المصالح ودفع المضار حتى لو كانت القواعد غير مضبوطة ضبطا تاما. وبهذا يجعل ابن القيم ما خرج على القاعدة الشرعية داخلا في قاعدة عامة أخرى تحقق المصلحة (19). رابعا: ذهب بعض الفقهاء والأصوليين إلى جواز

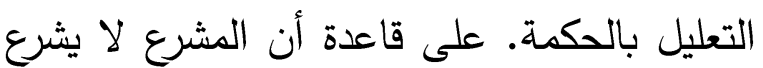
إلا لغاية وحكمة. لذلك كان الأساس في تنزيل الحكم في الحوادث هو معرفة هذه الغاية وتلك

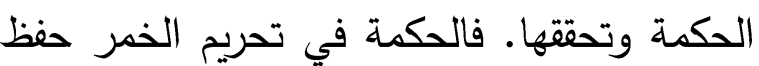

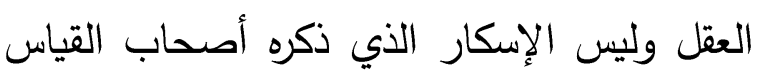
علة للحكم وقاسوا عليه. وقولهم بالإسكار يحد من الإن ليكاري

(197) (ابن تيمية ، حياته وعصره - آراؤه وفقهه) لهحمد أبو

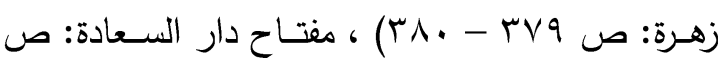

البالغة إلا بإذنها ورضاها وأجاز تزويج الثيب الصغيرة بغير رضاها قياسا على البكر الصغيرة. بينما جعل الثافعية العلة البكارة ، عدى الحكم

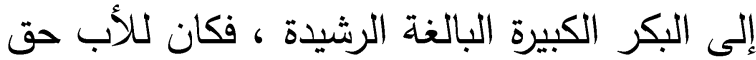
إجبارها على الزواج ، ولم يكن له حق إجبار الثيب الصغيرة عليه لعدم تحقق الحكمة فيها. وذهب ابن حزم إلى أنه يجبر بالصغر والبكارة معا ، وأجاز للأب تزويج ابنته البكر الصغيرة.

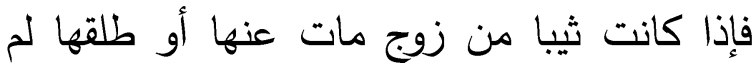
يجز للأب ولا لغيره أن يزوجها حتى تبلغ ، ولا إذن لهما قبل أن تبلغ. ثانيا: تتميز الحكمة على العلة. فالحكمة قائمة بذاتها واضحة كثيرا. أما العلة فقائمة بالأصل معرَّة للخفاء والتظنن. ومن المتقرر أن العلة في القياس وصف يقوم بالأصل ويقوم شبهه في الفرع. وقد تكون العلة منصوصة ، وقلما يحدث هذا ، وربما تكون واضحة أو خفية ، والأكثر أن تكون ظنية مختلفا فيها. أما الحكمة فهي قائمة بذاتها غير محتاجة إلى تشبيه فرع بأصل ، وواضحة وضوحا متفاوتا. وأدلة اعتبارها حاصلة من استقراء نصوص الثريعة. فقد تكون قطعية أو وضاو

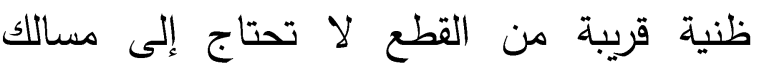
لاستتباطها. وبهذه الامتيازات نرى المصالح أجدر

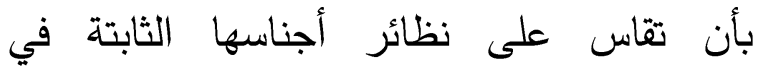
الثريعة، والمستقرأة من تصاريفها. ثالثا: من ثرات منهج ابن القيم في ربط الحكم بحكته الشرعية لا بعلته أمران: أولهما: أن الأقيسة الثرعية- كما يجريها ابن لهنه القيم - تبين مرامي الثارع ، وتوضح الأهداف الفئل 
شرائط المناطقة ، يوسع طرائق الاستتباط ، وينمي ، ولغي الفقه ، ويسمو بغاياته ، وذلك لقيامه على القواعد

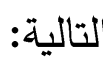

1 ا ـ أنه لا يوجد حكم شرعي بدون حكمة. r. الحكمة هي سبب الحكم وعلته. r. كل نص له حكمة شرعية معروفة ومصلحة مشروعة. - مان.

ع. العلة في لفظ ابن القيم هي الحكمة والمصلحة.

ه. يوافق ابن القيم على التعليل بالمظنة وعدم

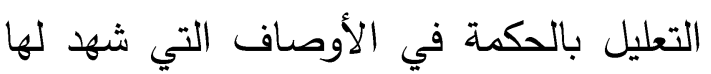
الشرع بالاعتبار فقط.

7. التعليل بالحكمة يصدر عن نظرة كلية للمقاصد الثرعية ، ويثر عن بيان المقاصد

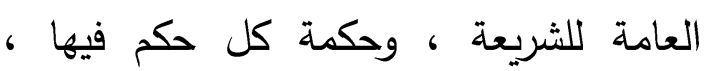

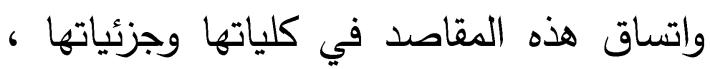
وتوافقها مع النصوص والقياس العقلي ، وبيان التجانس في الأحكام الثرعية.

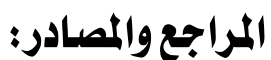

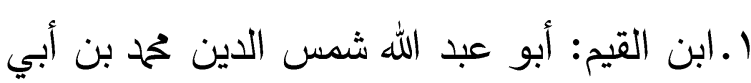
بكر ابن أيوب ، شفاء العليل في مسائل القدر

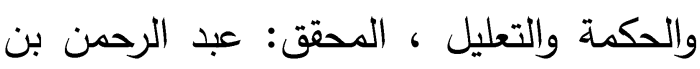

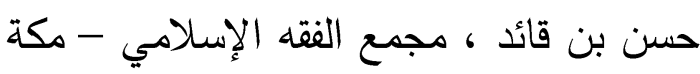

المكرمة ، ب آب اله.

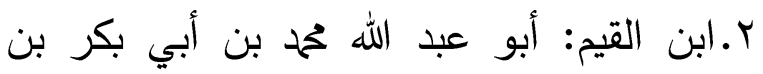

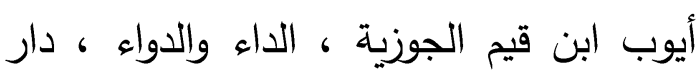

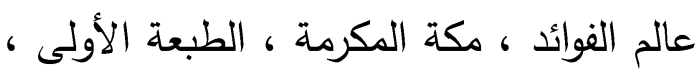

. $1 \leqslant$ r 9
تعدية الحكم إلى كل ما أضر بالعقل ، وقليل

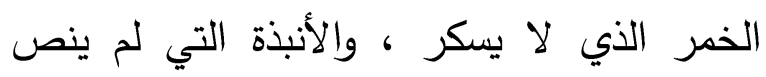

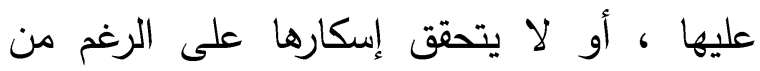

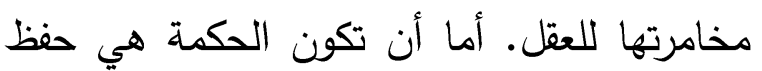

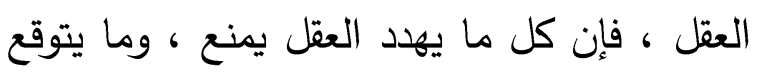
منه خطر يحظر ، ويدخل في ذلك المخدرات كالهيروين والكوكايين والأفيون.. وكل ما يستجد فئد

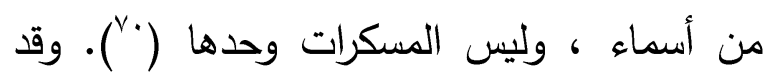
تكلم ابن القيم كثيرا عن أن العبرة بالمعاني والحكَ، لا بالأسماء والصور في التحليل والتحريم.

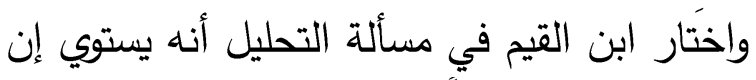

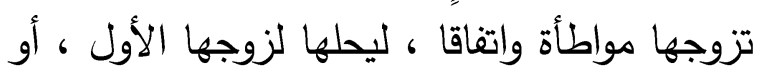

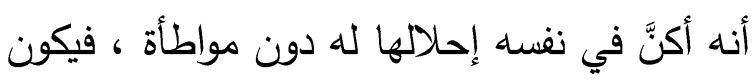

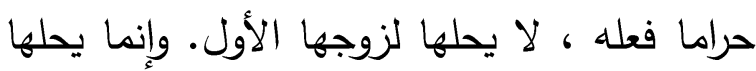

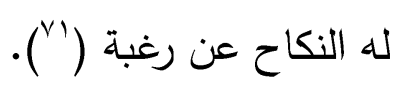

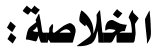

ونخلص مما ذكر أن ابن القيم قد أهتم بمسألة

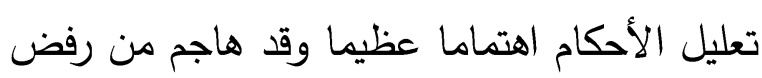

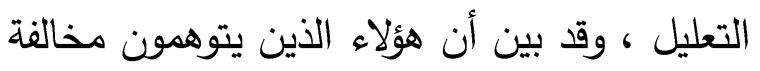

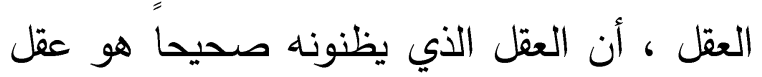

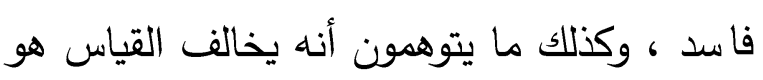
في الواقع القياس الذي توهموه هم ، وظنوا أند النه

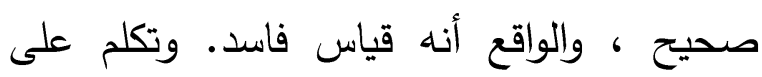

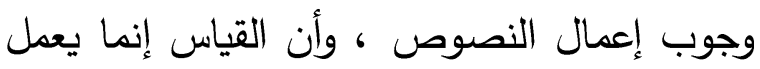

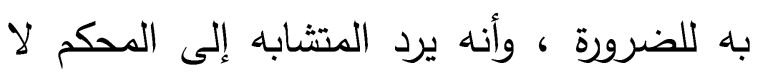
العكس. والقياس عند ابن القيم له سمات معينَّة: فهو قياس أثري ، مرن ، فطري ، متحرر من الن لهن

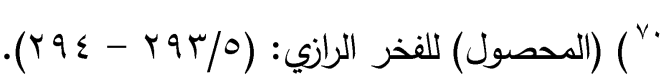

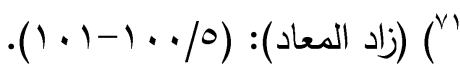


الحمد ، مجمع الفقه الإسلامي ، جدة ،

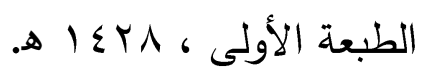

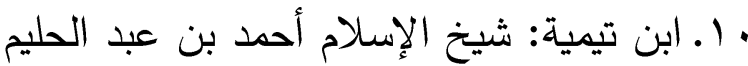

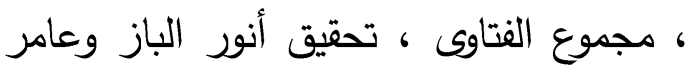
الجزار ، ، دار الوفاء ، مصر ، الطبعة الثالثة

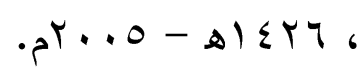

11 ا. ابن حزم: علي بن أحمد بن سعيد ، الإحكام

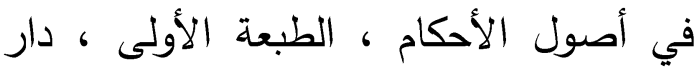

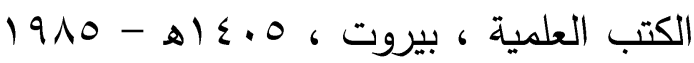

rا.ابن رجب الحنبلي: عبد الرحمن بن أحمد ، الذيل على طبقات الحنابلة ، المحقق: عبد الرحمن بن سليمان العثيمين ، مكتبة العبيكان

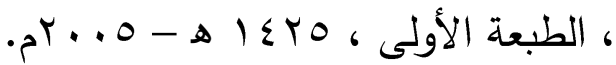
با.ابن عاشور: الثيخ محمد الطاهر ، تقسير

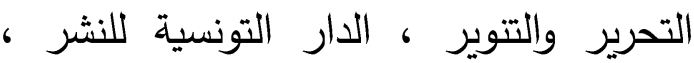

$$
\text { تونس ، ع } 9 \text { ام. }
$$

ع ا.ابن عاشور: الثيخ تحمح الطاهر ، مقاصد

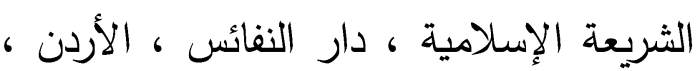

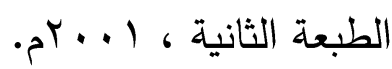
1 ا ـ ابن كثير : إسماعيل أبو الفذاء عماد الدين بن المن عمر بن كثير القرشي الدمشقي ، تفسير القرآن

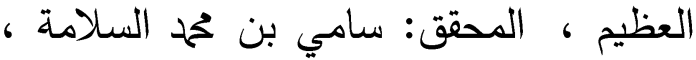

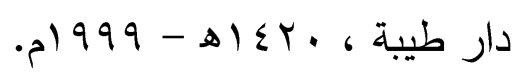

17 ا.ابن منظور: جمال الدين محم بن مكرم بن على ، لسان العرب ، دار إحياء التراث

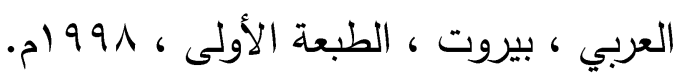

r.|بن القيم: أبو عبد الله ححم بن أبي بكر بن

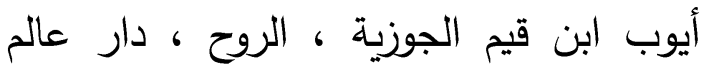

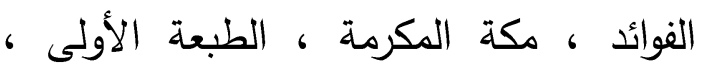
ه $1 \leqslant r T$ ع.ابن القيم: شمس الدين محمد بن أبي بكر ، إعلام الموقعين عن رب العالمين ، تحقيق تحمد عبد بلدي السلام إبراهيم ، دار الكتب العلمية ، بيروت ، العين كاعيف

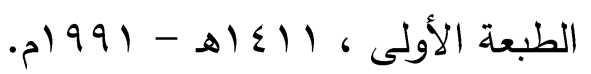

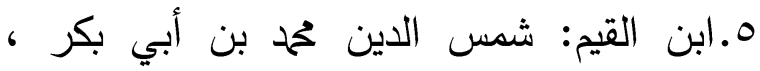
مدارج السالكين بين منازل إياك نعبد وإياك نستعين ، حققه وخرج أحاديثه وعلق عليه:

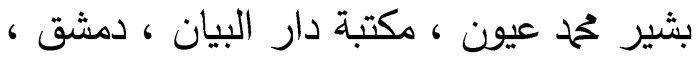

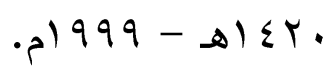

7.ابن القيم: شمس الدين تحمد بن أبي بكر ،

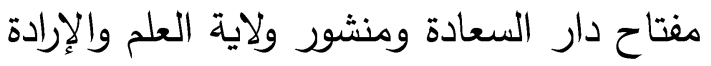
، المحقق: عبد الرحمن بن حسن بن قائد ، مجمع الفقه الإسلامي - جدة ، بrع اهـ.

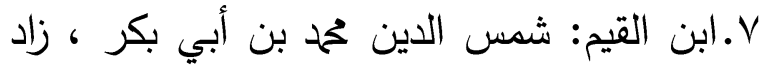

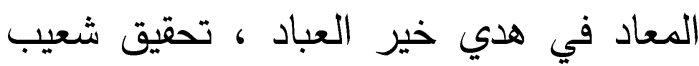
الأرنؤوط وعبد القادر الأرنؤوط ، مؤسسة

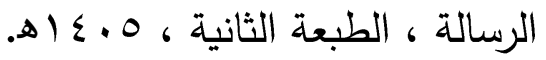

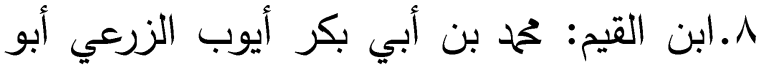

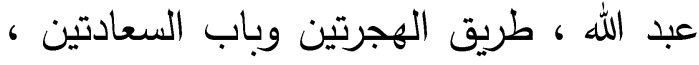
تحقيق: عمر بن محمود أبو عامر ، دار ابن

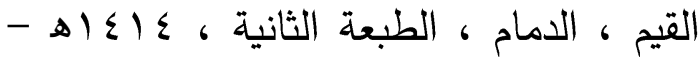
$.0199 \varepsilon$ 9.ابن القيم: حمحد بن أبي بكر بن أيوب ابن قيم

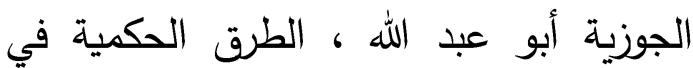
السياسة الشرعية ، تحقيق: نايف بن أحدد 
مr. الحموي: ياقوت بن عبد الله ، معجم البلدان ، دار صادر ، بيروت ، 990 ام.

جr. الخادمي: د. نور الدين بن مختار التونسي ، الاجتهاد المقاصدي "حجيته.. ضوابطه.. مجالاته" ، وزارة الأوقاف والشئون الإسلامية ،

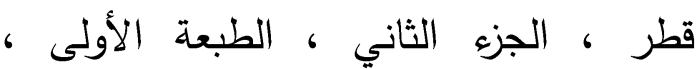

$$
.01991-81 \leq 19
$$

، rV دار الفكر العربي ، القاهرة. ^r. الرازي: أبو عبد الله ححم بن عمر بن الحسين التيمي ، المحصول في علم أصول الفقه ، تحقيق: د. طه جابر فياض العلواني ، مؤسسة

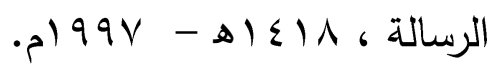

و ج. الرازي: حمح فخر الدين بن ضياء الدين ، ، مفاتيح الغيب=التفسير الكبير =تفسير الرازي

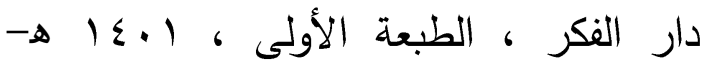
•p) 911 • س. الريسوني: د. أحمد عبد السلام ، نظرية المقاصد عند الإمام الشاطبي ، دار الكلمة ، مصر ، الطبعة الأولى ، ، إله . $199 \mathrm{~V}$

اس. الزبيدي: محمد بن محمد بن عبد الرزاق الحسيني المرتضى ، تاج العروس ، تحقيق عبد الستار أحمد فراج ، الطبعة الثانية ، طبعة الكويت. rr. السلمان: مساعد بن عبد الله ، أسرار الشريعة من أعلام الموقعين لابن القيم رحمه الله ، دار

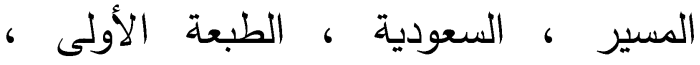
$.01991-\$ 1 \leqslant 11$
V أبو زهرة: الشيخ حمح ، ابن تيمية حياته ، وعصره - آراؤه وفقهه ، دار الفكر العربي لهوهي

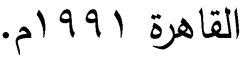
1 ا. أبو زهرة: الشيخ حمح ، ابن حنبل حياته

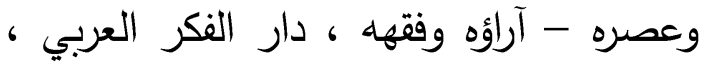

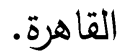
9 1ـ أبو زيد: بكر بن عبد الله ، ابن قيم الجوزية حياته آثاره موارده ، دار العاصمة للنشر والتوزيع ، المملكة العربية السعودية ، الطبعة

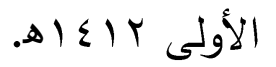

•r. الأشعري: أبو الحسن علي بن إسماعيل بن إسحاق ، مقالات الإسلاميين واختلاف المصلين ، دار فرانز شتايز ، ألمانيا ، الطبعة

$$
\text { الثالثة ، . . أه - . . 19 ام. }
$$

اب.الألباني: ححم ناصر الدين ، صحيح الجامع الصغير وزيادته (الفتح الكبير) ، المكتب

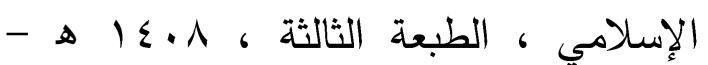
. $191 \mathrm{~N}$ r. البخاري: الإمام أبو عبد الله تحمد بن إسماعيل، الجامع الصحيح المسند (صحيح

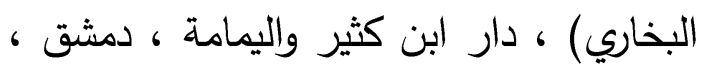
بيروت ، الطبعة الثالثة ، V • ع الهـ rr. البوطي: د. تحمد سعيد رمضان ، ضوابط المصلحة في الشريعة الإسلامية ، مؤسسة

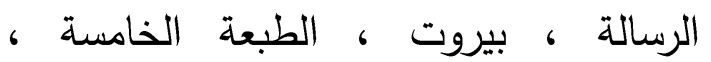
.ه) $\varepsilon \cdot 7$

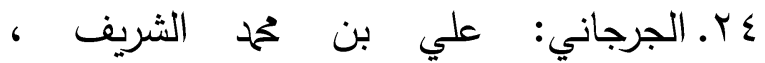
التعريفات، مطبعة الحلبي ، مصر ، IMOV . $19 \mu \wedge-$ 
الترجيح بينها ، مؤسسة شباب الجامعة ، الإنكندرية ، 910 ام.

9 ". جغيم: د. نعمان ، طرق الكثف عن مقاصد الثارع ، دار النفائس ، الأردن ، الطبعة دهان

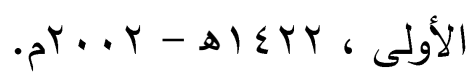

•ــ حمو: بشير إسماعيل ، ترجيحات الإمام ابن قيم الجوزية في كتابه شفاء العليل دراسة وتحليلا ، رسالة ماجستير ، كلية أصول

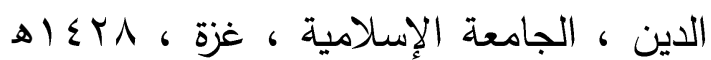

$$
\text { r. V V - }
$$

اء.زيدان: د. عبد الكريخ ، الوجيز في أصول

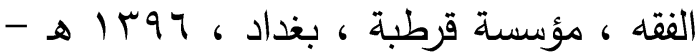

$$
\text { 19V7 }
$$

r. شلبي: د. محم مصطفى ، تعليل الأحكام ،

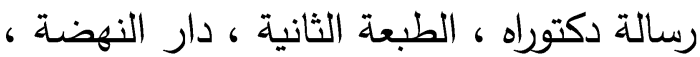

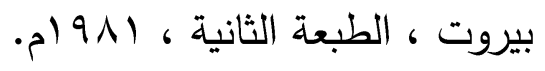

r؟ع. مسلم: أبي الحسن مسلم بن الحجاج النيسابوري ، الجامع الصحيح المسمى صحيح

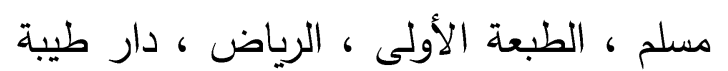

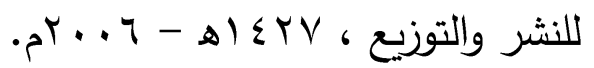

rr. السيوطي: جلال الدين ، سنن النسائي بشرح السيوطي وحاشية السندي ، المحقق: مكتب تحقيق التراث الإسلامي ، دار المعرفة،

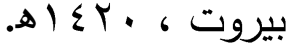
ع ז. العالم: د. يوسف حامد ، المقاصد العامة للشريعة الإسلامية ، الرياض ، الطبعة الثانية، $.0199 \varepsilon$ هب. العنزي: سعود بن ملوح سلطان ، سد الذرائع عند الإمام ابن قيم الجوزية وأثره في اختياراته

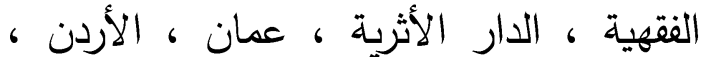

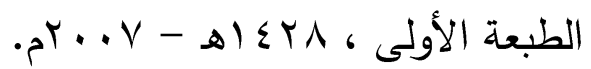

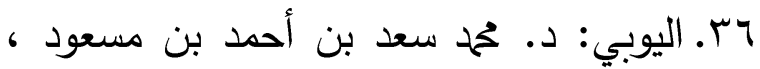

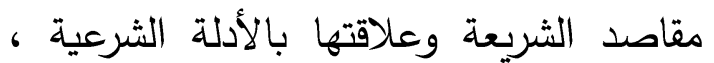

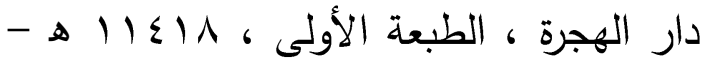
.01991 TV الوسيط ، مجمع اللغة العربية ، مكتبة الثروق

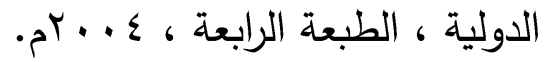

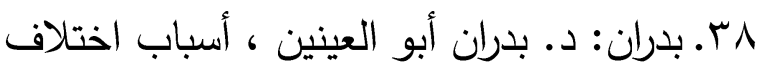

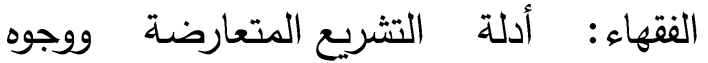

